\title{
Columbia County Habitat for Humanity Passive Townhomes
}

Jordan Dentz, Kunal Alaigh, and Devanshi Dadia

Advanced Residential Integrated Energy Solutions Collaborative 


\section{NOTICE}

This report was prepared as an account of work sponsored by an agency of the United States government. Neither the United States government nor any agency thereof, nor any of their employees, subcontractors, or affiliated partners makes any warranty, express or implied, or assumes any legal liability or responsibility for the accuracy, completeness, or usefulness of any information, apparatus, product, or process disclosed, or represents that its use would not infringe privately owned rights. Reference herein to any specific commercial product, process, or service by trade name, trademark, manufacturer, or otherwise does not necessarily constitute or imply its endorsement, recommendation, or favoring by the United States government or any agency thereof. The views and opinions of authors expressed herein do not necessarily state or reflect those of the United States government or any agency thereof.

Available electronically at SciTech Connect http:/www.osti.gov/scitech

Available for a processing fee to U.S. Department of Energy and its contractors, in paper, from:

U.S. Department of Energy

Office of Scientific and Technical Information

P.O. Box 62

Oak Ridge, TN 37831-0062

OSTI http://www.osti.gov

Phone: 865.576 .8401

Fax: 865.576.5728

Email: reports@osti.gov

Available for sale to the public, in paper, from:

U.S. Department of Commerce

National Technical Information Service

5301 Shawnee Road

Alexandria, VA 22312

NTIS http://www.ntis.gov

Phone: 800.553 .6847 or 703.605 .6000

Fax: 703.605.6900

Email: orders@ntis.gov 


\title{
Columbia County Habitat for Humanity Passive Townhomes
}

\author{
Prepared for: \\ The National Renewable Energy Laboratory \\ On behalf of the U.S. Department of Energy's Building America Program \\ Office of Energy Efficiency and Renewable Energy \\ 15013 Denver West Parkway \\ Golden, CO 80401 \\ NREL Contract No. DE-AC36-08GO28308
}

\author{
Prepared by: \\ Jordan Dentz, Kunal Alaigh, and Devanshi Dadia \\ The Advanced Residential Integrated Energy Solutions Collaborative \\ The Levy Partnership, Inc. \\ 1776 Broadway, Suite 2205 \\ New York, NY 10019 \\ NREL Technical Monitor: Stacey Rothgeb \\ Prepared under Subcontract No. KNDJ-0-40347-05
}

March 2016 
The work presented in this report does not represent performance of any product relative to regulated minimum efficiency requirements.

The laboratory and/or field sites used for this work are not certified rating test facilities. The conditions and methods under which products were characterized for this work differ from standard rating conditions, as described.

Because the methods and conditions differ, the reported results are not comparable to rated product performance and should only be used to estimate performance under the measured conditions. 


\section{Contents}

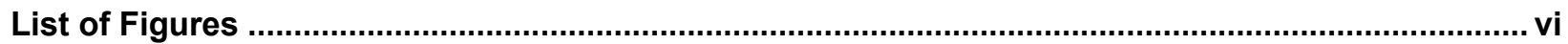

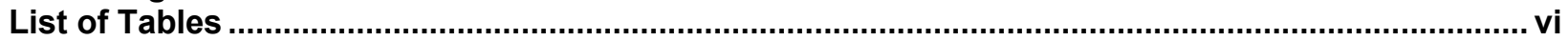

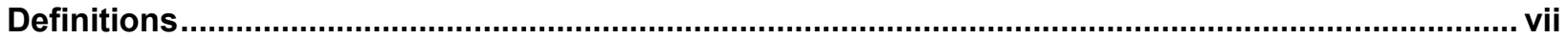

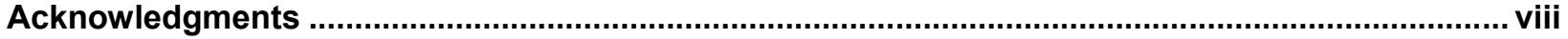

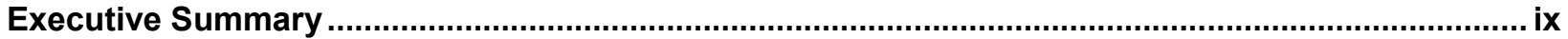

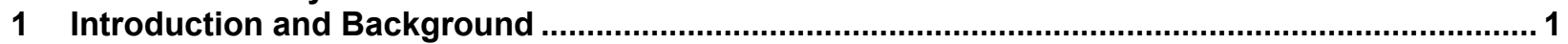

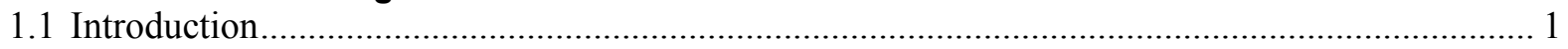

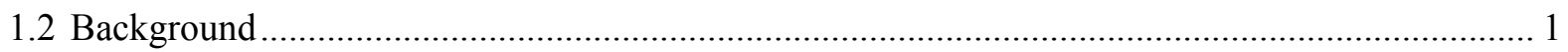

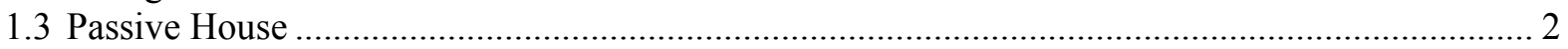

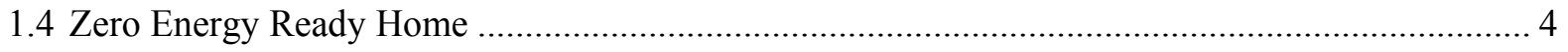

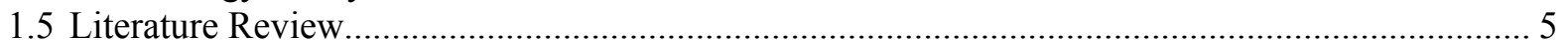

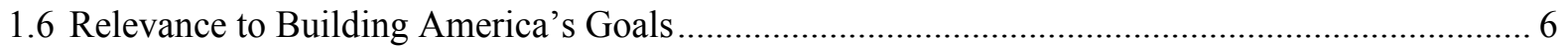

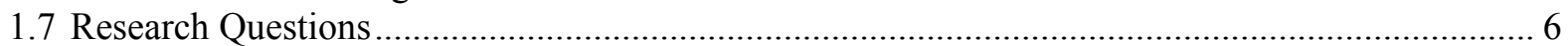

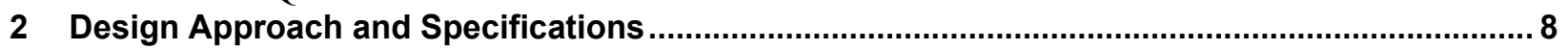

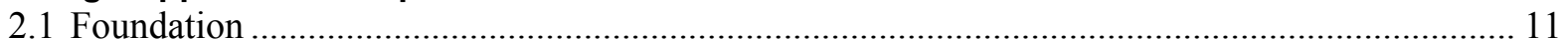

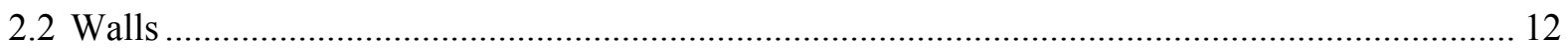

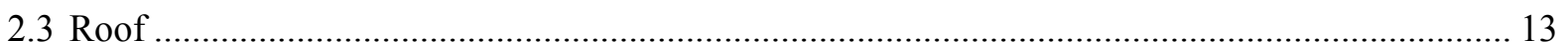

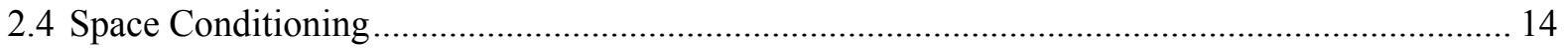

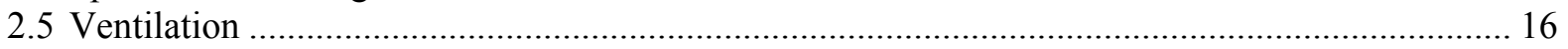

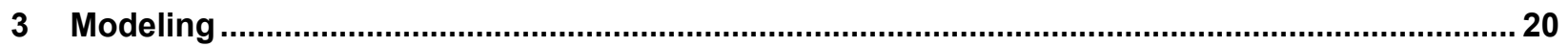

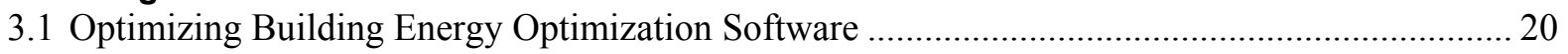

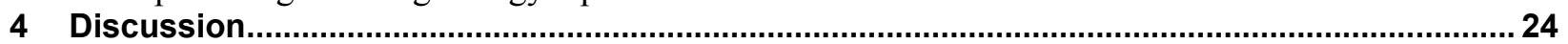

4.1 Challenges of High-Performance Certification with a Habitat Home ......................................... 24

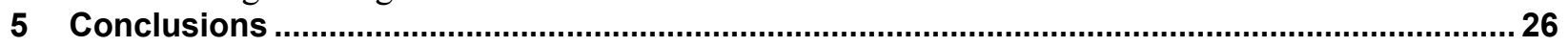

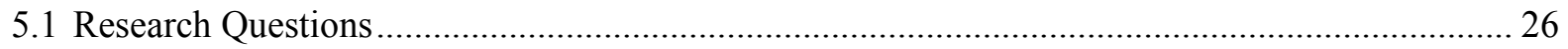

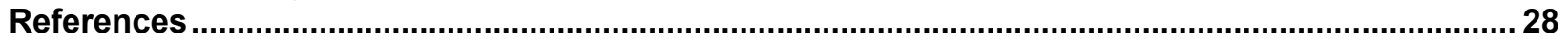

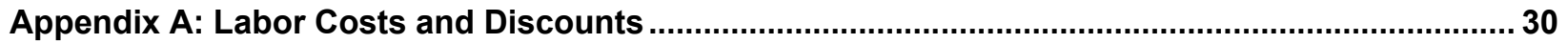

Appendix B: Building Energy Optimization Modeling Assumptions.......................................... 31

Appendix C: Photos of Columbia County Homes .......................................................................... 32 


\section{List of Figures}

Figure 1. Columbia County passive townhomes built in 2014-2015 ...........................................

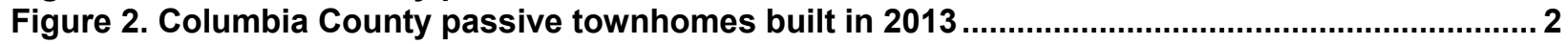

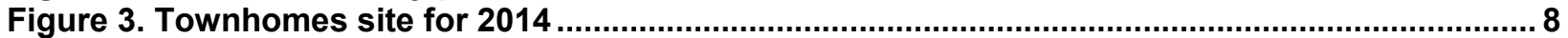

Figure 4. Second-floor plan (left); first-floor plan (right) .......................................................... 9

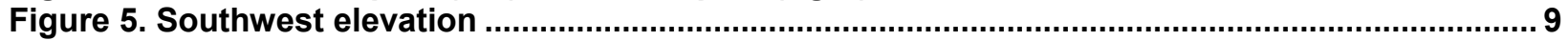

Figure 6. Northwest elevation (left); northeast elevation (right) .................................................. 10

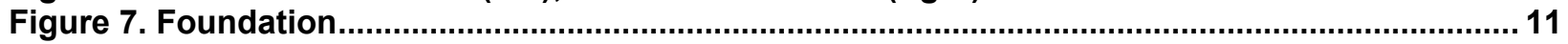

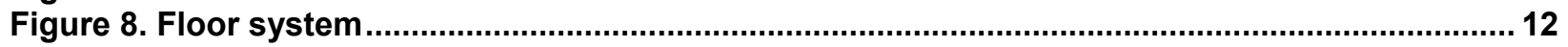

Figure 9. Wall construction-the $2 \times 6$ frame wall with air barrier membrane (blue) visible (left);

the SIPs installed (right) .................................................................................................. 12

Figure 10. Wall detail (red dashed line is airtight barrier) ............................................................ 13

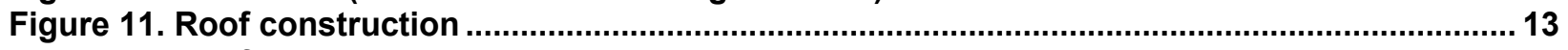

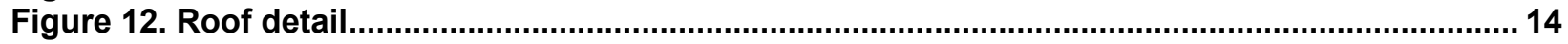

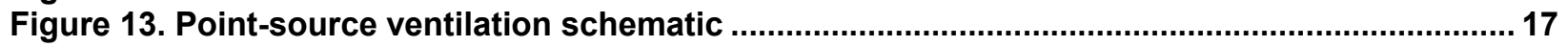

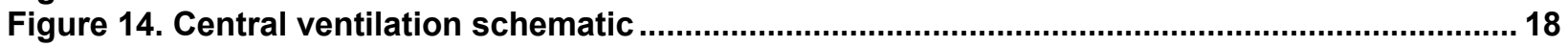

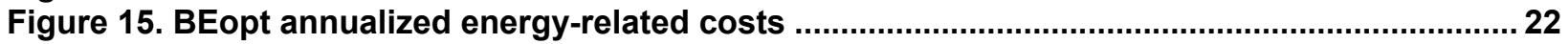

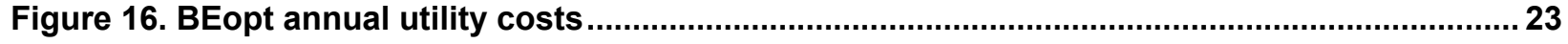

Unless otherwise indicated, all figures were created by the Advanced Residential Integrated Energy Solutions Collaborative.

\section{List of Tables}

Table 1. Basic Passive House Requirements (Passive House Institute 2015) ................................ 3

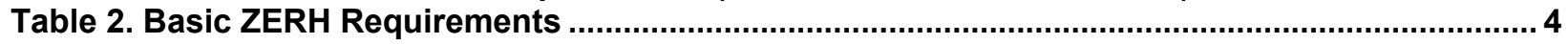

Table 3. Habitat for Humanity Passive House Projects .................................................................. 5

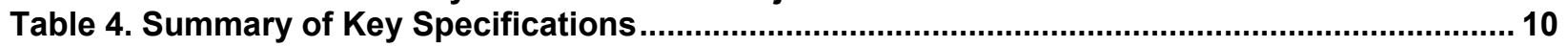

Table 5. Distributed Point-Source Ventilation System Major Components and Costs ..................... 18

Table 6. Central Ventilation System Major Components and Costs................................................... 19

Table 7. Comparison of Point-Source versus Central Ducted Ventilation System .......................... 19

Table 8. Comparison of Energy Models per Housing Unit .................................................................. 20

Table 9. Upgrade Costs: ENERGY STAR Version 3 versus Passive House Specifications.............. 21

Table 10. Habitat Material/Labor Costs and Discounts-Entire Project (Two Housing Units) .......... 30

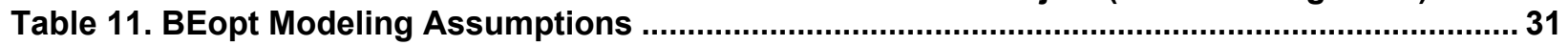

Unless otherwise indicated, all tables were created by the Advanced Residential Integrated Energy Solutions Collaborative. 


\section{Definitions}

$\begin{array}{ll}\text { BEopt }^{\mathrm{TM}} & \text { Building Energy Optimization software } \\ \text { CCHH } & \text { Columbia County Habitat for Humanity } \\ \text { HRV } & \text { Heat Recovery Ventilation, Heat Recovery Ventilator } \\ \text { IECC } & \text { International Energy Conservation Code } \\ \text { PHIUS } & \text { Passive House Institute U.S. } \\ \text { SIP } & \text { Structural Insulated Panel } \\ \text { ZERH } & \text { Zero Energy Ready Home }\end{array}$




\section{Acknowledgments}

The authors would like to express their appreciation to the project team including Brenda Adams of Columbia County Habitat for Humanity, Dennis Wedlick, Marc Bailey, and Chris Petrone of BarlisWedlick Architects and Don Hills of Hills Construction Management, as well as the many volunteers and vendors that helped bring this project to fruition. We are also grateful to Stacey Rothgeb of the National Renewable Energy Laboratory for guidance and support of this work. 


\section{Executive Summary}

Columbia County Habitat for Humanity (CCHH) (New York, Climate Zone 5A) built a pair of townhomes to Passive House Institute U.S. (PHIUS+ 2015) criteria to explore approaches for achieving Passive House performance (specifically with respect to exterior wall, spaceconditioning, and ventilation strategies) within the labor and budget context inherent in a Habitat for Humanity project. CCHH's goal is to eventually develop a cost-justified Passive House prototype design for future projects.

The townhomes were also certified under ENERGY STAR ${ }^{\circledR}$ New Homes Version 3 and the Zero Energy Ready Home program (DOE 2015). This was CCHH's second Passive House townhome project built in the past 2 years in an effort to explore various construction options for future Passive House work. The current project used a $2 \times 6$ frame wall with a structural insulated panel curtain wall and a vented attic over an air-sealed oriented strand board ceiling. Mechanical systems include one single-head, wall-mounted, ductless, mini-split heat pump in each unit and a heat-recovery ventilator.

Overall costs per unit were about $\$ 26,000$ higher for Passive House construction than for the same home built to the minimum specifications of ENERGY STAR Version 3; this represents about $18 \%$ of total construction costs. Building Energy Optimization Version 2.3 showed that modeled energy use of the Passive House design had 22.3\% lower source energy consumption than the ENERGY STAR Version 3 home. The largest cost component was the structural insulated panels, which represented about half of the added cost. Lower-cost approaches to achieving walls with high thermal integrity, such as double-wall framing (as used in the first set of Passive Townhomes), would likely be more cost-effective, presuming the volunteer labor force can achieve airtight construction. Evidence from the first pair of Passive Townhomes built in 2013 suggests that they can. Other significant upgrade costs were for the ventilation system, floor insulation, ceiling insulation, and doors. Windows were very low cost, partly because the manufacturer provided a discount to Habitat. The smaller space-conditioning system used in the Passive House saved about $\$ 2,700$ per home compared to a hypothetical ENERGY STAR design.

The U.S. Department of Energy's Building America research team Advanced Residential Integrated Energy Solutions Collaborative considered two alternative ventilation systems to address comfort, air-distribution effectiveness, and cost: (1) a central system, and (2) a pointsource system with small through-wall units distributed throughout the house. This report includes a design and cost analysis of these two approaches. Costs were similar, because a 30\% discount was provided to Habitat for the central system. Ultimately the central system was selected for this project, because the point-source units are not Passive House certified. However, compared to the central system used in this project, point-source systems are more cost-effective and practical for smaller homes (up to about 1,000 $\mathrm{ft}^{2}$ ) and for homes that are not seeking Passive House certification.

The homes were occupied during the spring and summer months, and residents have reported excellent results in terms of comfort. The residents have been following recommended operating procedures, including keeping the thermostat at a constant set point. Heating-season performance results are not yet available. 


\section{Introduction and Background}

\subsection{Introduction}

The U.S. Department of Energy's Building America research team Advanced Residential Integrated Energy Solutions Collaborative is led by The Levy Partnership. This team partnered with Columbia County Habitat for Humanity $(\mathrm{CCHH})$ and BarlisWedlick Architects to develop a Passive House townhome built in Hudson, New York (Figure 1 and Appendix C). The design is one of a series in an effort to develop a prototype solution for future projects built by $\mathrm{CCHH}$. In addition to meeting Passive House criteria, it was certified under U.S. Department of Energy Zero Energy Ready Home, ENERGY STAR ${ }^{\circledR}$ New Homes Version 3, and Environmental Protection Agency Indoor airPLUS (EPA 2013) programs.

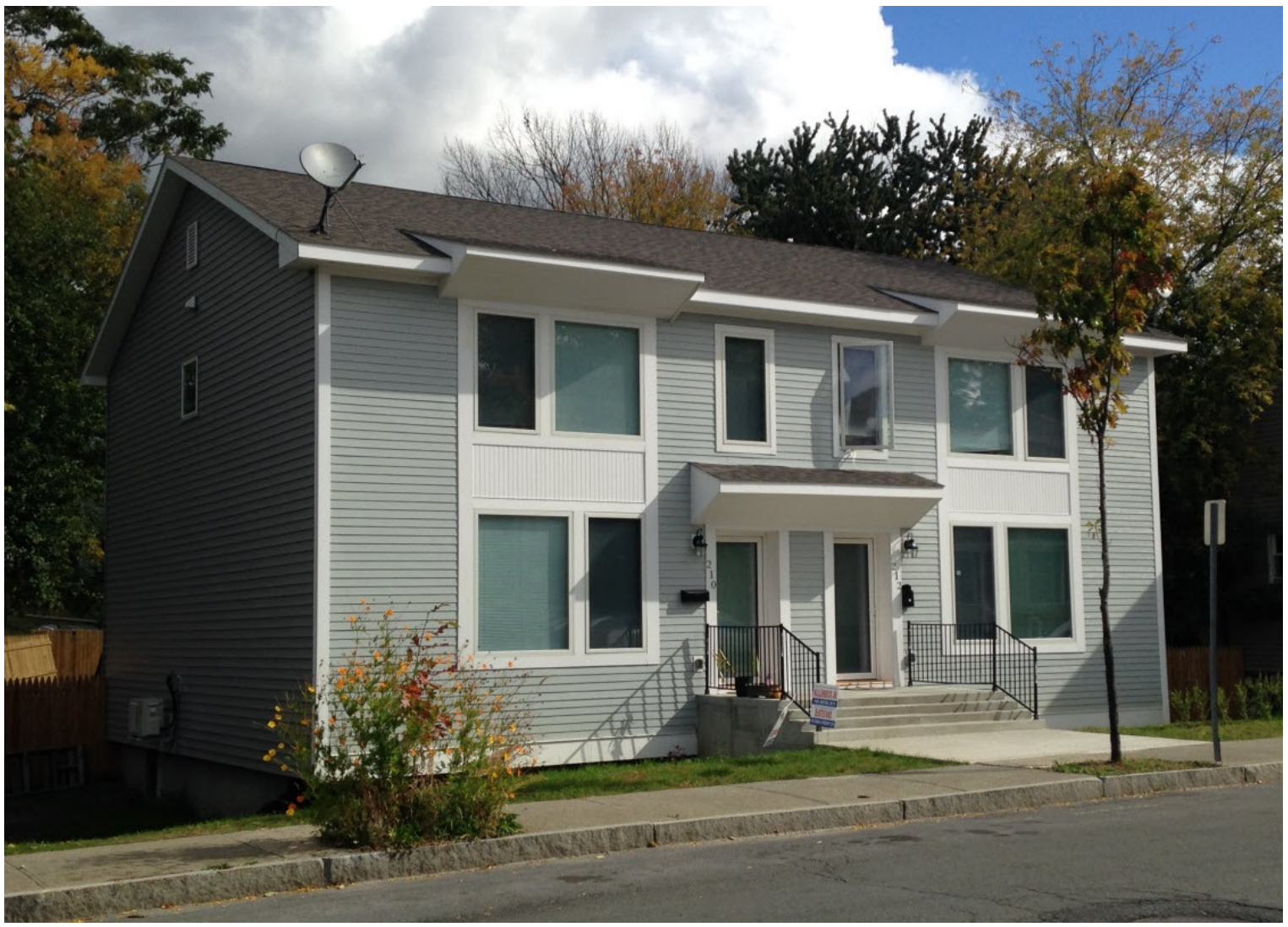

Figure 1. Columbia County passive townhomes built in 2014-2015

\subsection{Background}

$\mathrm{CCHH}$ was founded in 1993 to serve Columbia County, New York (CCHH 2013). To date the organization has built 18 homes - 5 at the ENERGY STAR level and 4 at Passive House or nearPassive House level. The Advanced Residential Integrated Energy Solutions Collaborative monitored an earlier townhome development built by CCHH in 2013, which was built to nearPassive House standards (Figure 2) (The Levy Partnership, Inc. and CDH Energy Corp. 2014). The parent organization, Habitat for Humanity International, is one of the top 10 homebuilders in the United States; it typically builds or rebuilds more than 10,000 homes annually through a network of affiliates nationwide (Habitat for Humanity 2014). CCHH has decided to pursue 
energy-efficient building, including Passive Houses, so its homeowners can benefit from longterm energy savings and low maintenance costs.

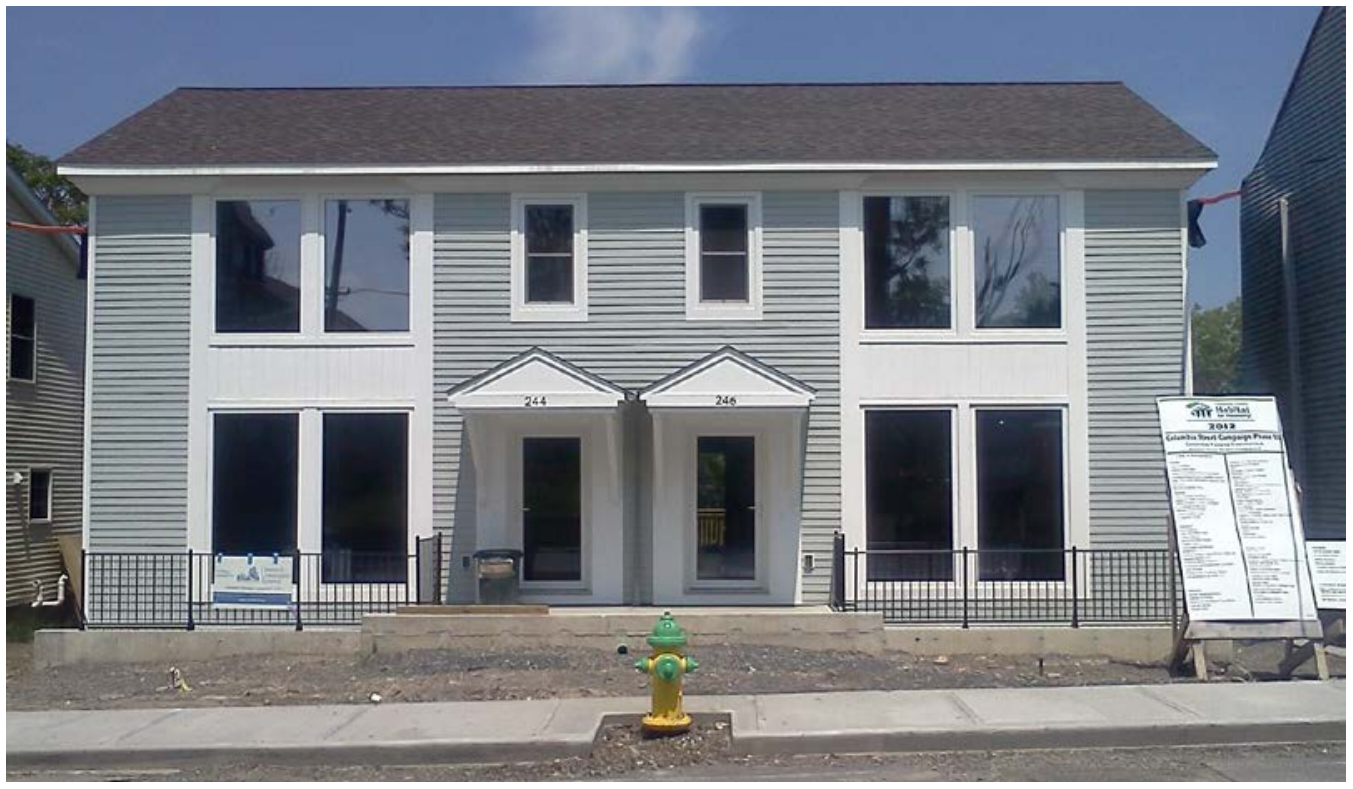

Figure 2. Columbia County passive townhomes built in 2013

\subsection{Passive House}

Passive Houses rely on a combination of superior envelope insulation, airtight construction, efficient mechanical equipment, and heat-recovery ventilation (HRV) technologies to reduce space-heating needs by $80 \%$ or more compared to homes built to the minimum code standards (Feist et al. 2005). Passive Houses use the building's design to retain internal heat gains, thereby reducing loads on heating equipment (Passive House Institute U.S. 2011). Basic requirements for International Passive House certification are listed in Table $1 .{ }^{1}$

Passive House certification may be attained in the United States through one of two channels: through agencies affiliated with the Passive House Institute in Darmstadt, Germany, which certifies using Passive House Institute standards, or through the PHIUS+ program run by Passive House Institute U.S. (PHIUS). As part of its certification program, PHIUS requires certification by the U.S. Department of Energy Zero Energy Ready Home (ZERH), formerly the U.S. Department of Energy Challenge Home (DOE 2013), as a prerequisite.

\footnotetext{
${ }^{1}$ During the course of this project PHIUS certification standards (one of two pathway options for Passive House certification available in the United States) were revised to provide for climate-dependent criteria. Details about the new standards are available on the PHIUS website: www.phius.org/home-page.
} 
Table 1. Basic Passive House Requirements (Passive House Institute 2015)

\begin{tabular}{c|c}
\hline Area & Requirement \\
\hline $\begin{array}{c}\text { Space-Heating } \\
\text { Energy Demand }\end{array}$ & $\begin{array}{r}\text { Energy demand must not exceed } 15 \mathrm{kWh} / \mathrm{m}^{2} / \mathrm{yr} \text { of net living space }(4.75 \\
\left.\mathrm{kBtu} / \mathrm{ft}^{2}-\mathrm{yr}\right) \text { and must be lower than } 10 \mathrm{~W} / \mathrm{m}^{2} \text { peak demand }\left(34 \mathrm{Btu} / \mathrm{h}-/ \mathrm{ft}^{2} \text { - }\right. \\
\mathrm{yr}) .\end{array}$ \\
$\begin{array}{c}\text { Space-Cooling } \\
\text { Energy Demand }\end{array}$ & $\begin{array}{r}\text { In climates where active cooling is needed, the requirement roughly matches } \\
\text { the space-heating energy demand requirements, with a small additional } \\
\text { allowance for dehumidification. }\end{array}$ \\
$\begin{array}{c}\text { Primary Energy } \\
\text { Demand }\end{array}$ & $\begin{array}{r}\text { Total primary (source) energy (heating, cooling, hot water, lighting, } \\
\text { appliances, etc.) must not exceed } 120 \mathrm{kWh} / \mathrm{m}^{2} / \mathrm{yr} \text { of net living space (38 } \\
\left.\mathrm{kBtu} / \mathrm{ft}^{2}-\mathrm{yr}\right) .\end{array}$ \\
Airtightness & $\begin{array}{r}\text { Airtightness must be a xaximum of } 0.6 \text { air changes per hour at } 50 \text { Pascals } \\
\text { pressure (ACH50), in both pressurization and depressurization. }\end{array}$ \\
Thermal Comfort & $\begin{array}{r}\text { Thermal comfort must be met for all living areas during winter and summer, } \\
\text { with not more than } 10 \% \text { of hours per year over } 25^{\circ} \mathrm{C}\left(\sim 77^{\circ} \mathrm{F}\right) .\end{array}$ \\
\hline
\end{tabular}

Alternative Passive House criteria were released in 2015 by PHIUS for use in North America, which is the standard this project used for meeting Passive House requirements. These criteria were developed in collaboration with the Building America program (Wright and Klingenberg 2015) to modify the international requirements based on local climate factors and, to a lesser degree, on building costs and energy prices. The following major changes are included:

- The airtightness requirement, verified through a blower door test, was changed from 0.6 $\mathrm{ACH} 50$ to $0.05 \mathrm{CFM} 50 / \mathrm{ft}^{2}$ of gross envelope area (or $0.08 \mathrm{CFM} 75$ ) to avoid punishing smaller buildings with larger envelope-to-volume ratios.

- The source energy factor for grid electricity was adjusted from 2.6 (European Passive House Planning Package standard) to 3.16 (the U.S. national average).

- For residential projects the source energy limit was changed to per person rather than per square foot of floor area limit. The source energy limit was temporarily set at $6,200 \mathrm{kWh}$ per person per year (reducing to $4,200 \mathrm{kWh}$ at a future point to be determined), in part to compensate for the high source-energy factor. The limit is applied after considering the estimated on-site renewable electricity generated that is used onsite.

- The space-conditioning criteria were adjusted based on economic feasibility by local climate conditions and include mandatory thresholds for annual heating and cooling demands and peak heating and cooling loads.

- Lighting and miscellaneous-plug-load defaults were changed to $80 \%$ of the Residential Energy Services Network standard (about six times greater than Passive House Planning Package defaults).

- Instead of using the German method of "treated floor area," which subtracts floor area taken up by building elements such as doors, partitions, chimneys, and stairs, PHIUS now 
uses "interior conditioned floor area," which is a simplified interior-dimension floor area (Holladay 2015).

The hard requirements for Passive House certification, whether via the international standard or the revised PHIUS standard, generally require the following measures at a minimum in cold and temperate climates:

- Insulation: Opaque building envelope components should have a heat-transfer coefficient (U-value) no higher than $0.15 \mathrm{~W} /\left(\mathrm{m}^{2} \mathrm{~K}\right)\left(0.09 \mathrm{Btu} / \mathrm{h} / \mathrm{ft}^{2} /{ }^{\circ} \mathrm{F}\right)$ (at least $\left.\mathrm{R}-11\right)$.

- Windows: Window frames must be well insulated and fitted with low-e glazings filled with argon or krypton to prevent heat transfer. This generally means a U-value of 0.80 $\mathrm{W} /\left(\mathrm{m}^{2} \mathrm{~K}\right)\left(0.46 \mathrm{Btu} / \mathrm{h} / \mathrm{ft}^{2} /{ }^{\circ} \mathrm{F}\right)$ or less, with solar heat gain values around $50 \%$.

- Ventilation: Efficient HRV is essential to enable good indoor air quality without energy waste. At least $75 \%$ of the heat from the exhaust air must be transferred to the fresh air again by means of a heat exchanger.

- Thermal bridges: All edges, corners, connections, and penetrations must be planned and executed with great care so that thermal bridges can be avoided or minimized.

Additional quality requirements (soft criteria) also apply to ensure occupant comfort; satisfaction (e.g., low equipment noise, ventilation quality, and occupant control); and building durablility (e.g., no condensation) (Passipedia 2014).

\subsection{Zero Energy Ready Home}

ZERH certification requires that the home qualify for the Environmental Protection Agency's ENERGY STAR label (Version 3) and Indoor airPLUS label. ENERGY STAR Version 3 requires insulation based on the 2009 International Energy Conservation Code (IECC 2009), but the ZERH program increases this requirement to the provisions of the 2012 and 2015 IECCs, depending on the home's location. The ZERH program includes provisions for energy efficiency, comfort, durability, and indoor air quality (DOE 2015). Basic requirements for ZERH certification are included in Table 2.

Table 2. Basic ZERH Requirements

\begin{tabular}{c|c}
\hline Area & Mandatory Requirements \\
\hline $\begin{array}{c}\text { ENERGY STAR } \\
\text { for Homes }\end{array}$ & Homes are certified under ENERGY STAR Qualified Homes Version 3 or \\
Envelope & $\begin{array}{c}\text { Fenestration meets or exceeds latest ENERGY STAR requirements. } \\
\text { Ceiling, wall, floor, and slab insulation meets or exceeds 2012 IECC levels } \\
\text { (or 2015 IECC if 2012 is local code). }\end{array}$ \\
Duct System & $\begin{array}{r}\text { Ducts located within the home's thermal and air-barrier boundary or } \\
\text { optimized to achieve comparable performance. }\end{array}$ \\
Water Efficiency & $\begin{array}{c}\text { Hot water delivery systems meet efficient design requirements (which } \\
\text { require that the hot water distribution system stores no more than 0.5 gal of } \\
\text { water in any piping/manifold between the hot water source and any hot } \\
\text { water fixture). }\end{array}$ \\
\hline
\end{tabular}




\begin{tabular}{|c|c|}
\hline Area & Mandatory Requirements \\
\hline \multirow{3}{*}{$\begin{array}{l}\text { Lighting and } \\
\text { Appliances }\end{array}$} & $\begin{array}{c}\text { All installed refrigerators, dishwashers, and clothes washers are ENERGY } \\
\text { STAR qualified. }\end{array}$ \\
\hline & $\begin{array}{l}\text { Eighty percent of the lighting fixtures are ENERGY STAR qualified or } \\
\text { there are ENERGY STAR lamps (bulbs) in a minimum of } 80 \% \text { of the } \\
\text { sockets. }\end{array}$ \\
\hline & $\begin{array}{l}\text { All installed bathroom ventilation and ceiling fans are ENERGY STAR } \\
\text { qualified. }\end{array}$ \\
\hline $\begin{array}{l}\text { Indoor Air } \\
\text { Quality }\end{array}$ & $\begin{array}{l}\text { Indoor air quality must be certified under the Environmental Protection } \\
\text { Agency’s Indoor airPLUS (which requires additional moisture, radon, and } \\
\text { pest controls along with final combustion appliance and materials checks } \\
\text { [EPA 2013]). }\end{array}$ \\
\hline $\begin{array}{l}\text { Renewable } \\
\text { Ready }\end{array}$ & $\begin{array}{l}\text { The home must follow the Consolidated Renewable Energy Ready Home } \\
\text { Checklist. (Preparations for a future photovoltaic array are required only if } \\
\text { the location has at least } 1.585 \mathrm{kBtu} / \mathrm{ft}^{2} / \text { day }\left[5 \mathrm{kWh} / \mathrm{m}^{2} / \text { day] average daily }\right. \\
\text { solar radiation, the roof is not shaded, and sufficient roof area is oriented } \\
\text { within } 45^{\circ} \text { of south.) }\end{array}$ \\
\hline
\end{tabular}

\subsection{Literature Review}

In 2010 Habitat for Humanity International U.S. Council mandated that by 2015 all new houses built by local affiliates are to be constructed to meet energy-efficiency standards (Habitat for Humanity 2015; Gonzales 2010). A number of Habitat chapters have taken that guidance to heart and attempted to build Passive Houses. A literature search was conducted to research the Passive House experience of other Habitat for Humanity chapters. Eight U.S. Habitat chapters constructed Passive Houses or near-Passive Houses (not all houses were formally certified). These are summarized in Table 3. Additional Passive House projects may have been built by Habitat affiliates since this review was completed.

Table 3. Habitat for Humanity Passive House Projects

\begin{tabular}{|c|c|c|}
\hline Habitat Chapter & Project & Description \\
\hline $\begin{array}{l}\text { Habitat for Humanity } \\
\text { of Washington, D.C. }\end{array}$ & Empowerhouse & $\begin{array}{l}\text { Two-family home insulated with dense-pack } \\
\text { cellulose; originally part of the } 2011 \text { U.S. } \\
\text { Department of Energy Solar Decathlon (Foster } \\
\text { 2011). As of April 2015, six additional Passive } \\
\text { Houses are currently being built in the Ivy City } \\
\text { neighborhood (Orton 2012). }\end{array}$ \\
\hline $\begin{array}{l}\text { Habitat for Humanity } \\
\text { of Southern Santa } \\
\text { Barbara County }\end{array}$ & $\begin{array}{l}\text { Canon Perdido } \\
\text { Affordable } \\
\text { Homes }\end{array}$ & $\begin{array}{l}\text { Twelve attached homes insulated with fiberglass and } \\
\text { open-cell spray foam; planned for completion in } \\
2014 \text { (Gibson 2014). Three are intended for Passive } \\
\text { House certification. }\end{array}$ \\
\hline $\begin{array}{l}\text { Green Mountain } \\
\text { Habitat for Humanity }\end{array}$ & Charlotte, VT & $\begin{array}{l}\text { 1,487- } \mathrm{ft}^{2} \text { modular home completed in } 2010 \text { and } \\
\text { planned as one of three homes (Defendorf 2010) }\end{array}$ \\
\hline
\end{tabular}




\begin{tabular}{c|c|c}
\hline Habitat Chapter & Project & Description \\
\hline $\begin{array}{c}\text { Habitat for Humanity } \\
\text { of Madison \& Clark } \\
\text { Counties }\end{array}$ & Berea, KY & $\begin{array}{c}1,100-\mathrm{ft}^{2} \text { single-family home built in 2012 with } \\
\text { double stud walls with high-density fiberglass batt } \\
\text { insulation (Warren 2012) }\end{array}$ \\
$\begin{array}{c}\text { Habitat for Humanity } \\
\text { of Gallatin Valley }\end{array}$ & $\begin{array}{c}\text { Idaho Street } \\
\text { Passive House }\end{array}$ & $\begin{array}{c}\text { 1,600- } \mathrm{ft}^{2} \text { single-family home using modified Larsen } \\
\text { truss walls (Gonzales 2010) }\end{array}$ \\
$\begin{array}{c}\text { Habitat for Humanity } \\
\text { in Whatcom County }\end{array}$ & $\begin{array}{c}\text { Bellingham, } \\
\text { WA }\end{array}$ & $\begin{array}{c}\text { Three Passive-style single-family homes (Habitat for } \\
\text { Humanity in Whatcom County 2012) }\end{array}$ \\
$\begin{array}{c}\text { Tounty Habitat for } \\
\text { Humanity }\end{array}$ & $\begin{array}{c}\text { Ainsworth } \\
\text { Vista }\end{array}$ & $\begin{array}{c}1,232-\mathrm{ft}^{2} \text { single-family home completed in 2013 } \\
\text { (Tacoma/Pierce County Habitat for Humanity 2015) }\end{array}$ \\
$\begin{array}{c}\text { Columbia County } \\
\text { Habitat for Humanity }\end{array}$ & $\begin{array}{c}\text { Hudson } \\
\text { Passive } \\
\text { Townhomes }\end{array}$ & $\begin{array}{c}\text { Near-passive duplex completed in 2013; precursor } \\
\text { for the 2014 townhome project described in this }\end{array}$ \\
\hline
\end{tabular}

\subsection{Relevance to Building America's Goals}

This project will help answer the following questions listed in the U.S. Department of Energy's Statement of Need (DOE 2013):

- What are the most cost-effective, most durable, and easiest-to-implement options for high-R-value envelopes in new homes?

- Which low-load space-conditioning systems provide the best performance in all climates and building types?

- Given a fixed budget, what are the optimal investments in enclosure and spaceconditioning upgrades that provide the best overall improvements in home performance?

\subsection{Research Questions}

This work explores approaches for achieving PHIUS+ 2015 performance (specifically with respect to exterior wall, space-conditioning, and ventilation strategies) with the cost constraints inherent in a Habitat for Humanity project. The analysis also includes a comparison to codeminimum and ENERGY STAR Version 3 minimum construction. It resulted in a case study for high-efficiency affordable housing.

CCHH's goal was to develop and test a prototype design. The objectives of the Advanced Residential Integrated Energy Solutions Collaborative were to help $\mathrm{CCHH}$ achieve this goal and address the following research questions:

1. What low-cost, high-R-value, and airtight envelope system is suitable for new attached homes in IECC Climate Zone 5 that can be successfully implemented by a largely volunteer labor force? What are the costs and resulting performance characteristics? 
2. How can point-source space-conditioning (and possibly ventilation) systems be successfully implemented into moderately sized, low-load, affordable townhomes in IECC Climate Zone 5? What are the costs and performance characteristics?

3. What are the costs and systems-integration issues associated with a super-insulated, highperformance, affordable townhome project in Climate Zone 5? How can these issues be successfully resolved? 


\section{Design Approach and Specifications}

The project site is shown in Figure 3; the street façade is oriented southwest. Solar exposure to the south helps the design take advantage of passive solar opportunities. Each two-story duplex home has a compact configuration with living areas and a study on the first floor, and three bedrooms on the second floor (Figure 4). Most glazing is on the street façade to take advantage of the solar exposure (see Appendix C). Overhangs shade some of the windows to mitigate heat in summer (Figure 6, Figure 6, and Appendix C).

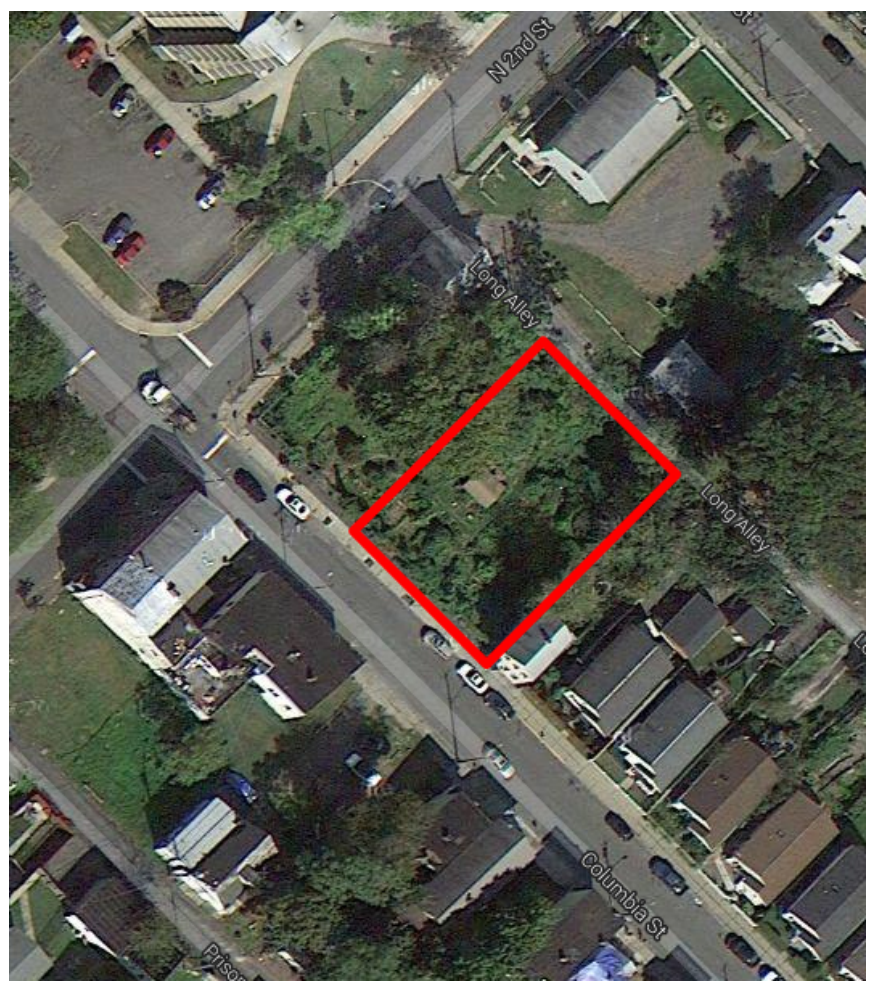

Figure 3. Townhomes site for 2014 

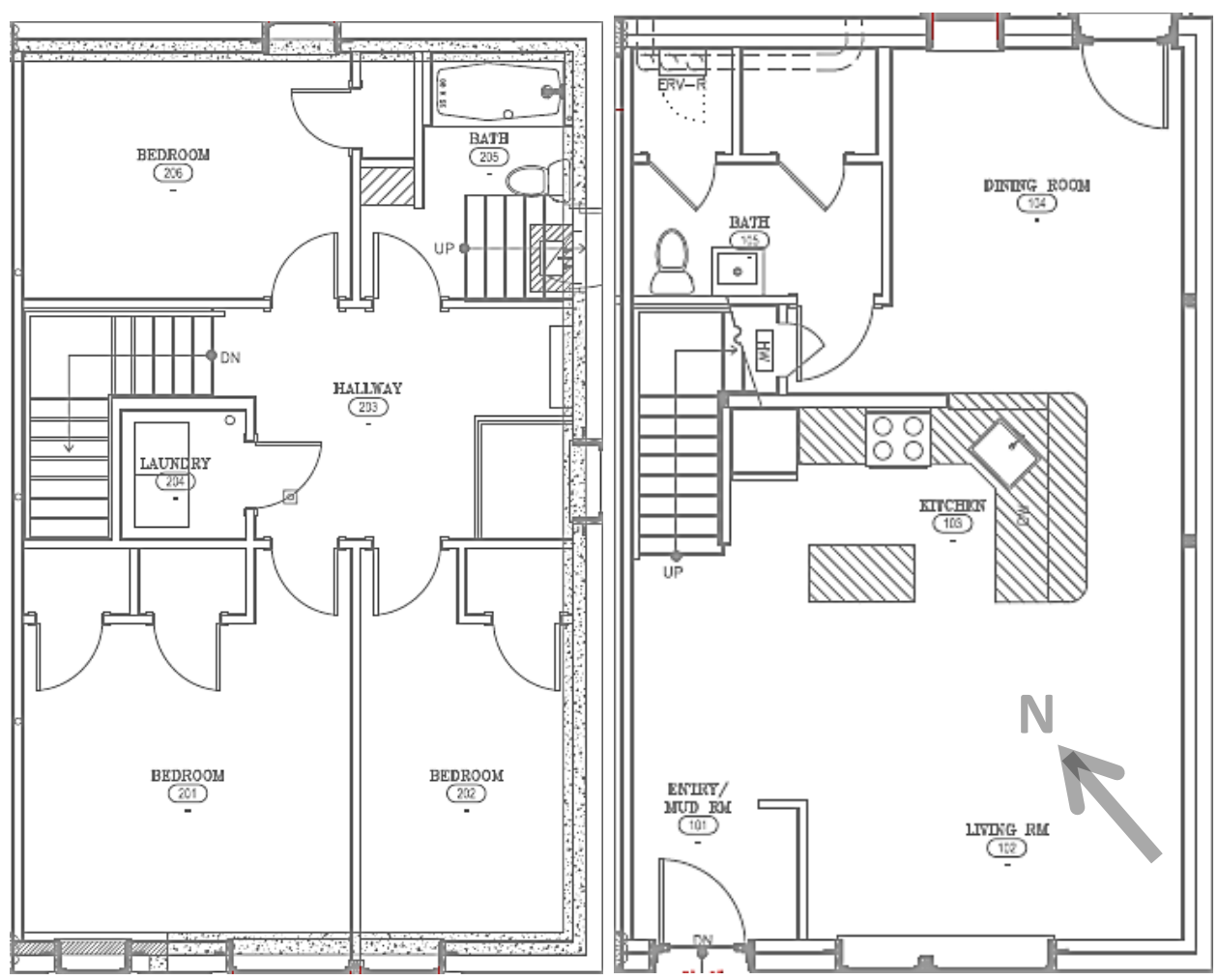

Figure 4. Second-floor plan (left); first-floor plan (right)

Source: BarlisWedlick Architects

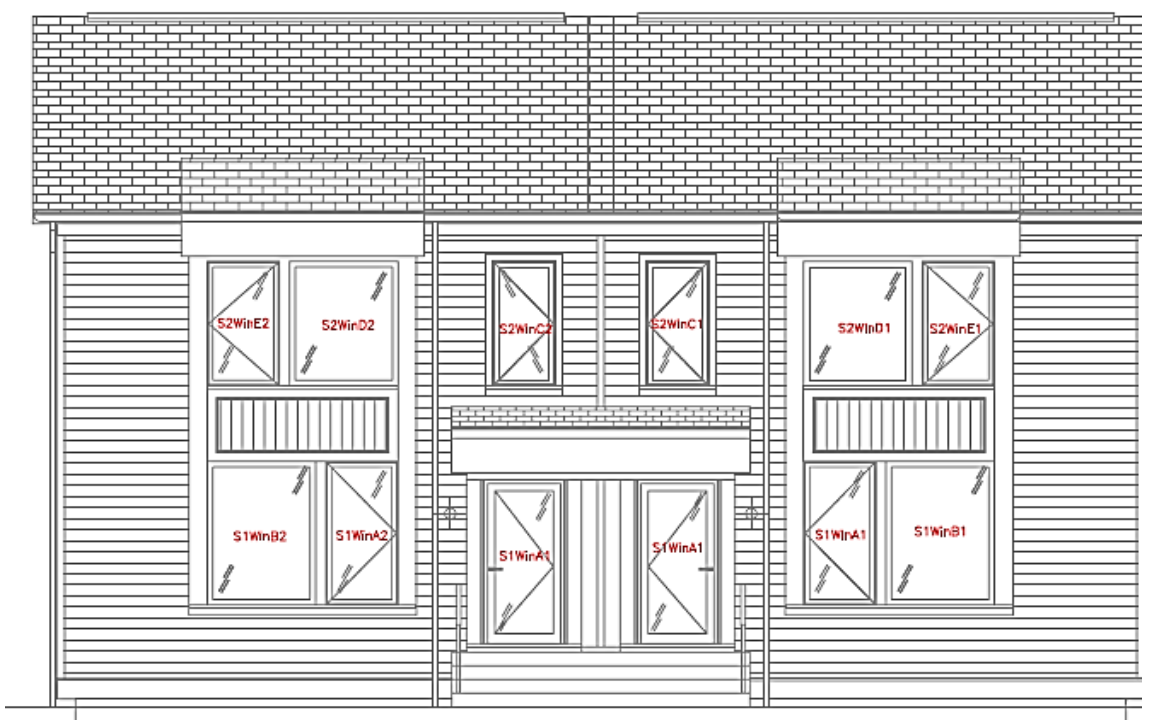

Figure 5. Southwest elevation

Source: BarlisWedlick Architects 

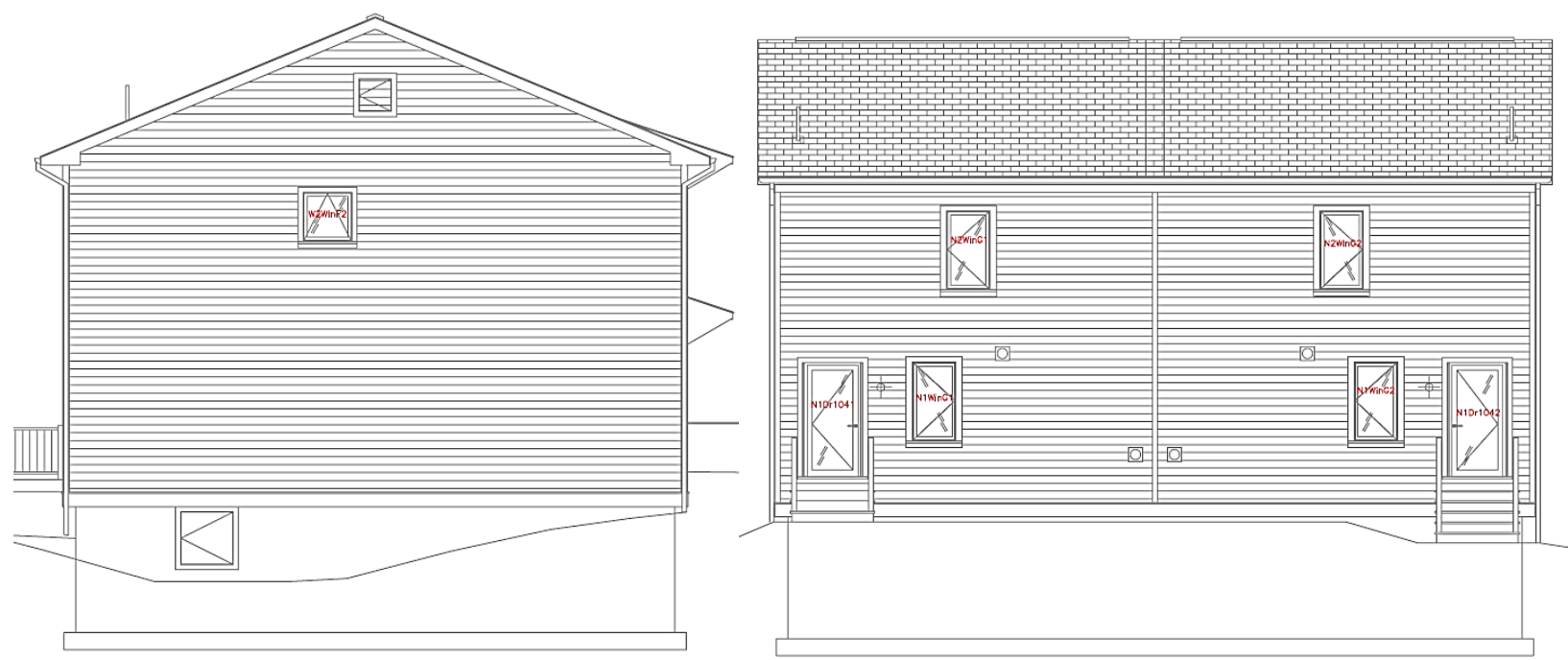

Figure 6. Northwest elevation (left); northeast elevation (right)

Source: BarlisWedlick Architects

A summary of key specifications is included in Table 4 and described in detail in the following sections.

Table 4. Summary of Key Specifications

\begin{tabular}{|c|c|}
\hline Area & Specifications \\
\hline Floor & $\begin{array}{l}\text { Frame floor above unconditioned basement with } 9.25 \text {-in. dense-pack } \\
\text { cellulose and } 8 \text {-in. Neopor expanded polystyrene. }{ }^{\mathrm{a}} \text { Total R-value of } 68.9 \text {. }\end{array}$ \\
\hline Walls & $\begin{array}{l}\text { Nominal 8-in. thick Neopor structural insulated panels (SIPs) attached to } 2 \\
\times 6 \text { wall framing filled with dense-pack cellulose. Clear-wall R-value of } \\
52.5 \text {. }\end{array}$ \\
\hline Roof & $\begin{array}{l}\text { Truss roof with 24-in. cellulose. Total R-value in the attic floor (in field) of } \\
\text { roof R-90.9; lower at the eaves. }\end{array}$ \\
\hline Windows & $\begin{array}{l}\text { Alpen double-glazed plus interior film with unplasticized polyvinyl } \\
\text { chloride frame. Assembly U-value } 0.19 \text { at the north and } 0.18 \text { at the south } \\
\text { façade. Glazing SHGC } 0.38 \text { at north and } 0.56 \text { at the south façade. }\end{array}$ \\
\hline Doors & Klearwall-Saint Gobain. Assembly U-factor of 0.16. Glazing SHGC 0.49. \\
\hline $\begin{array}{c}\text { Space } \\
\text { Conditioning }\end{array}$ & $\begin{array}{l}\text { One 12-kBtu Mitsubishi ductless mini-split heat pump unit per home; } \\
\text { indoor head located on second floor near floor opening. SEER }{ }^{\mathrm{c}} 26.1 \text {, } \\
\operatorname{HSPF}^{\mathrm{d}} 12.5 \text {, coefficient of performance at } 47^{\circ} \mathrm{F} \text { of } 3.43 \text {. }\end{array}$ \\
\hline $\begin{array}{l}\text { Whole-House } \\
\text { Ventilation }\end{array}$ & $\begin{array}{l}\text { One ComfoAir } 200 \mathrm{HRV} \text { per home with distribution by Zehnder } \\
\text { ComfoTube system. Heat recovery efficiency } 92 \% \text {. }\end{array}$ \\
\hline Airtightness & 0.80 АCH50. \\
\hline
\end{tabular}




\begin{tabular}{c|c}
\hline Area & Specifications \\
\hline $\begin{array}{c}\text { Domestic } \\
\text { Water } \\
\text { Heating }\end{array}$ & Electric tank water heater model Whirlpool, 40 gal, energy factor 0.95 \\
Appliances & ENERGY STAR refrigerator, dishwasher, and clothes washing machine \\
Lighting & $100 \%$ compact fluorescent lamps, light-emitting diodes, or pin-fluorescents \\
Fans & ENERGY STAR ceiling fan installed at second floor landing area \\
\hline
\end{tabular}

${ }^{a}$ Neopor is a BASF product that contains graphite within a polymer matrix of rigid expanded polystyrene foam. The graphite particles both reflect and absorb radiant energy, thereby increasing the material's insulation capacity, while retaining (BASF).

${ }^{\mathrm{b}}$ Solar heat gain coefficient

${ }^{\mathrm{d}}$ Seasonal energy efficiency ratio

${ }^{\mathrm{d}}$ Heating seasonal performance factor

\subsection{Foundation}

The previous Columbia Passive Townhomes built in 2013 were placed over a full conditioned basement. A slab-on-grade foundation was initially planned to reduce costs of the new project; however, due to a steeply sloped site and high water table it was designed with an unconditioned basement with access through an external hatch (Figure 7). This kept costs down compared to a conditioned basement, simplified the thermal envelope, and allowed $\mathrm{f}$ the exposed floor air barrier to be inspected and repaired from below during blower door testing. Also, because cool air from the point-source cooling system would tend to settle to the lowest level of the house, the lack of a basement connected to the living space would keep cool air in the main living space during summer, which was a comfort concern that emerged in the 2013 near-Passive Houses.

Figure 8 shows details of the floor system. An air barrier membrane runs from the rim joist (where it is taped to the wall membrane) over the top of the foundation wall and under the floor, where it is taped to the Neopor insulation.
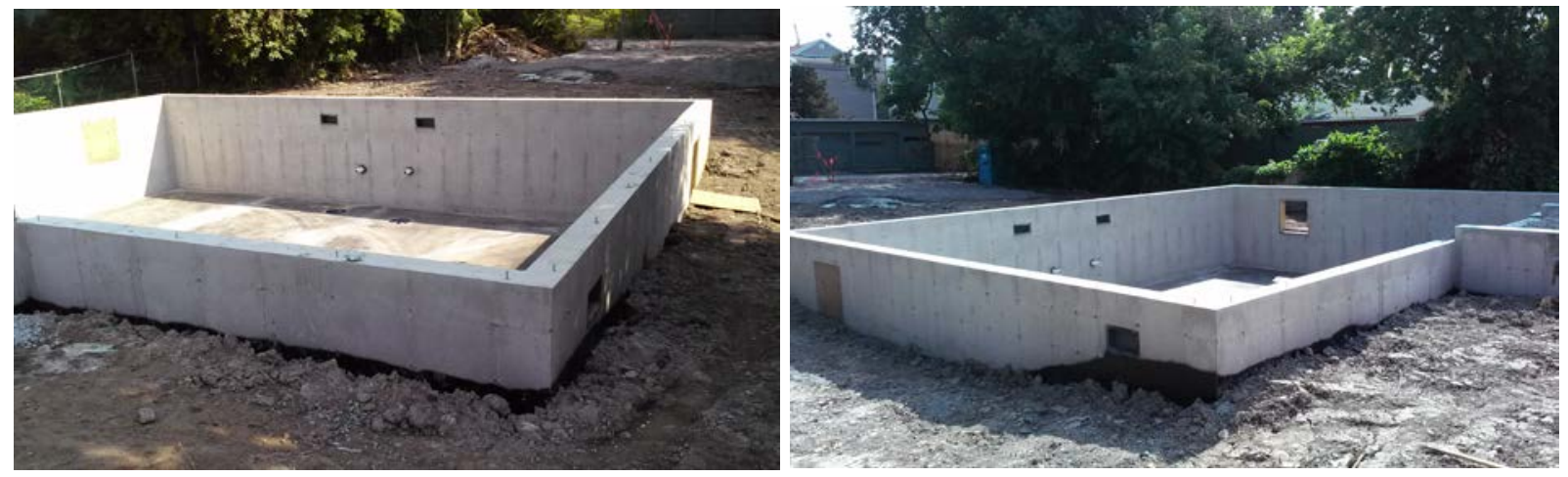

Figure 7. Foundation 


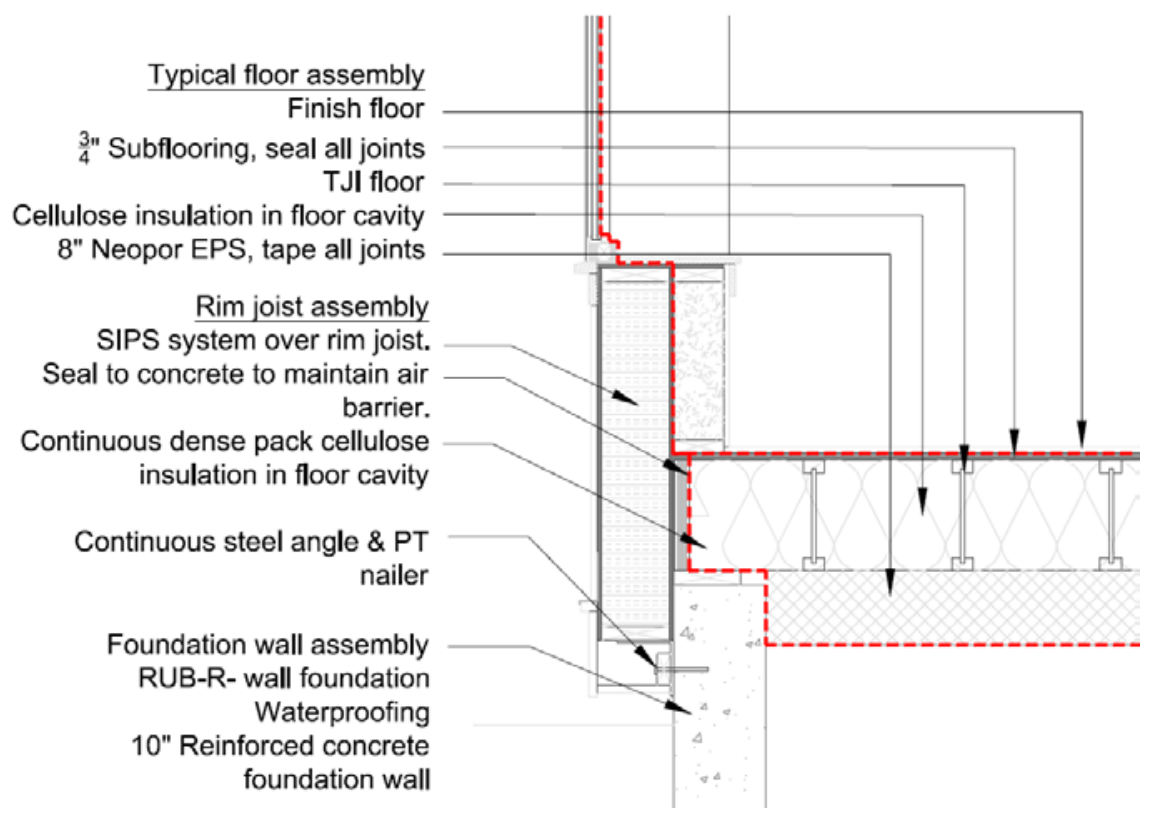

Figure 8. Floor system

Source: BarlisWedlick Architects

\subsection{Walls}

The project team elected to use SIPs based on previous success in achieving airtight construction. Rather than full-wall thickness SIPs, 8-in.-thick SIPs with an R-value of 34.6 were used to reduce costs. A $2 \times 6$ frame wall provided the structure, allowed for additional insulation, and took advantage of volunteer labor. This resulted in a framed wall with a SIP curtain wall outboard of the frame (Figure 9 and Figure 10). An air barrier consisting of an air-sealed, vaporpermeable membrane was applied to the exterior of the wall frame before the SIPs were installed. The framed section of the wall was filled with dense-pack cellulose insulation (R-value 20.9) and used for services. Windows were installed in the SIPs.

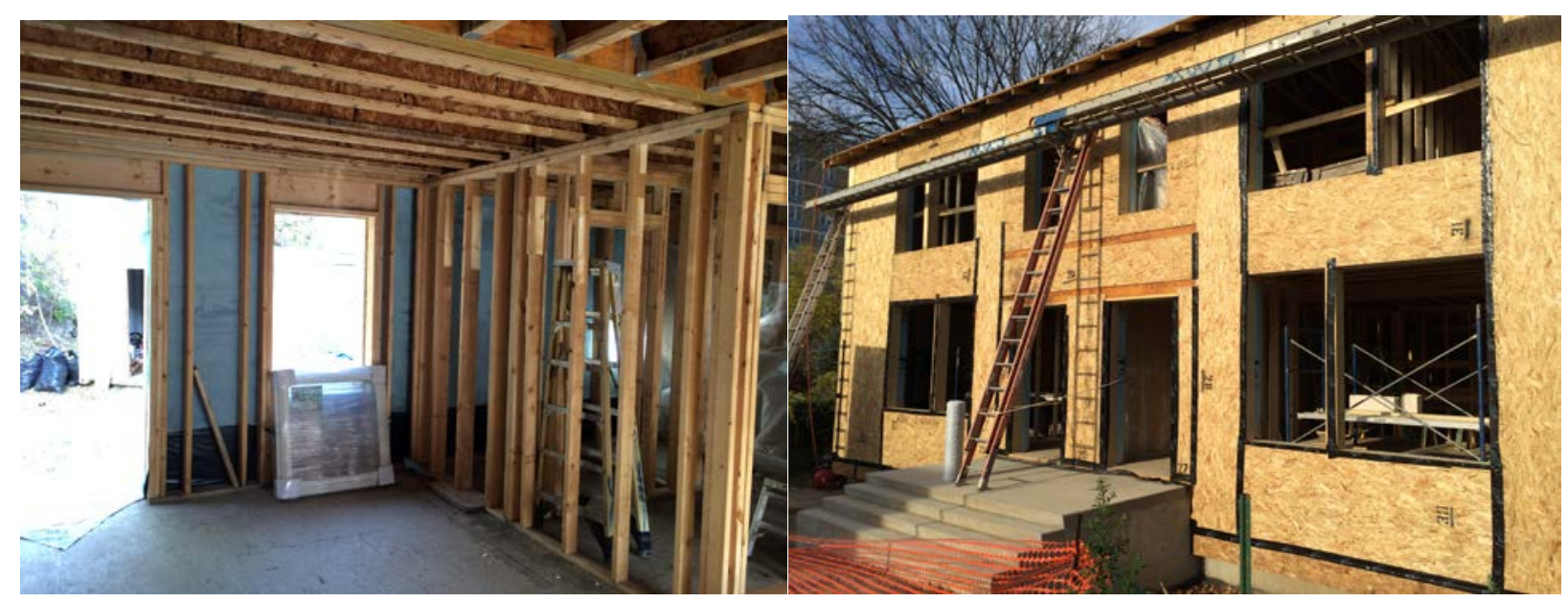

Figure 9. Wall construction-the $2 \times 6$ frame wall with air barrier membrane (blue) visible (left); the SIPs installed (right) 


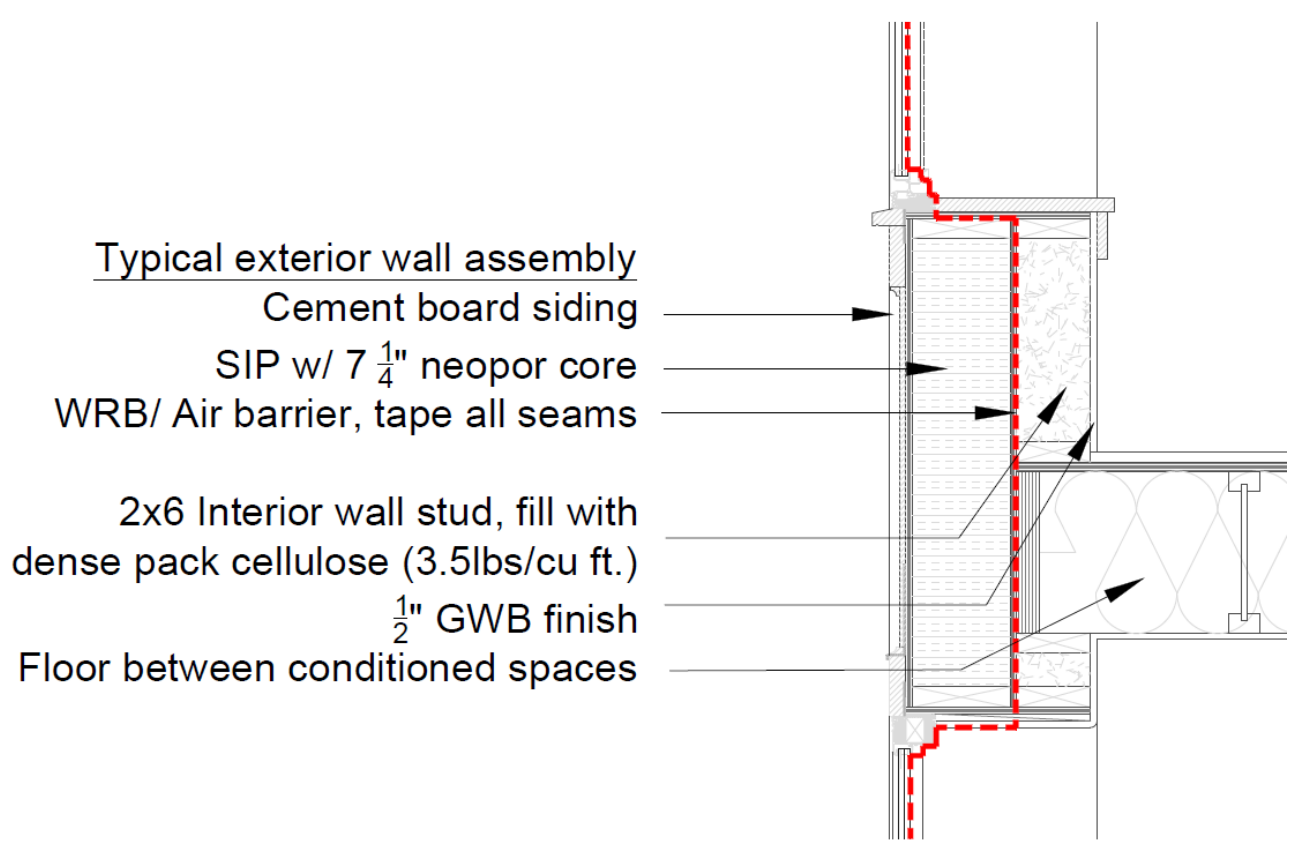

Figure 10. Wall detail (red dashed line is airtight barrier)

Source: BarlisWedlick Architects

\subsection{Roof}

A ventilated truss roof was installed and filled with cellulose insulation (Figure 11 and Figure 12). A continuous oriented strand board air barrier was installed below the trusses.

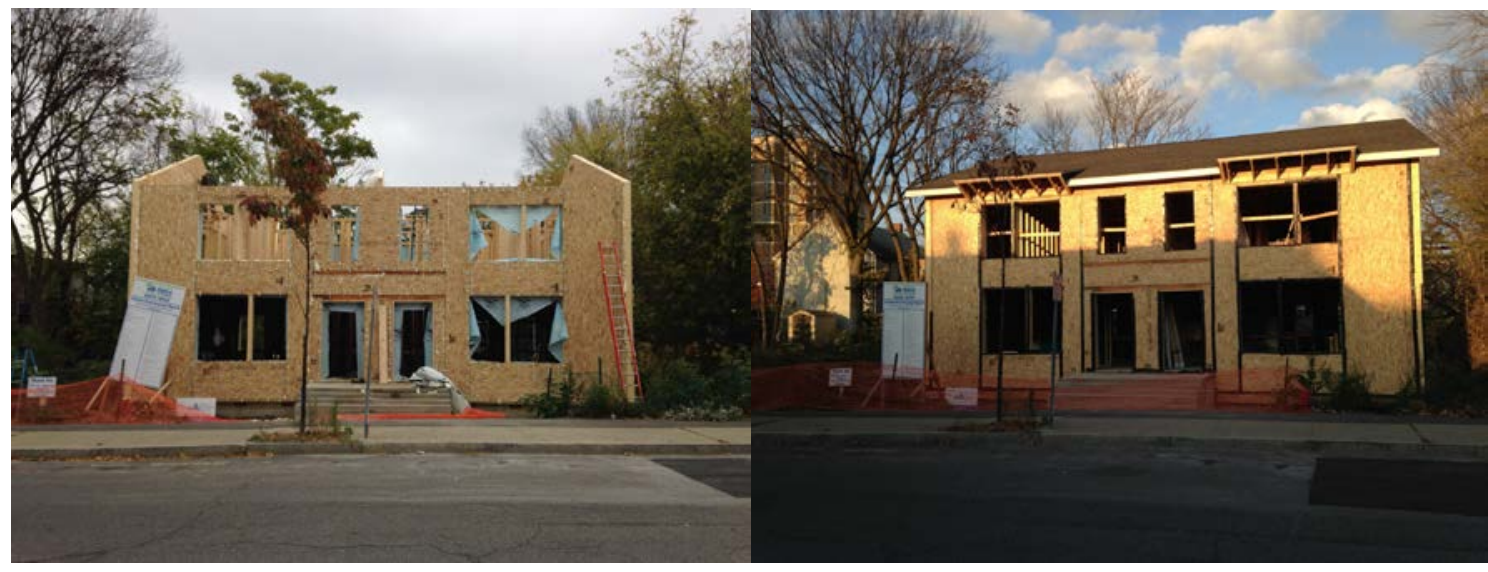

Figure 11. Roof construction 


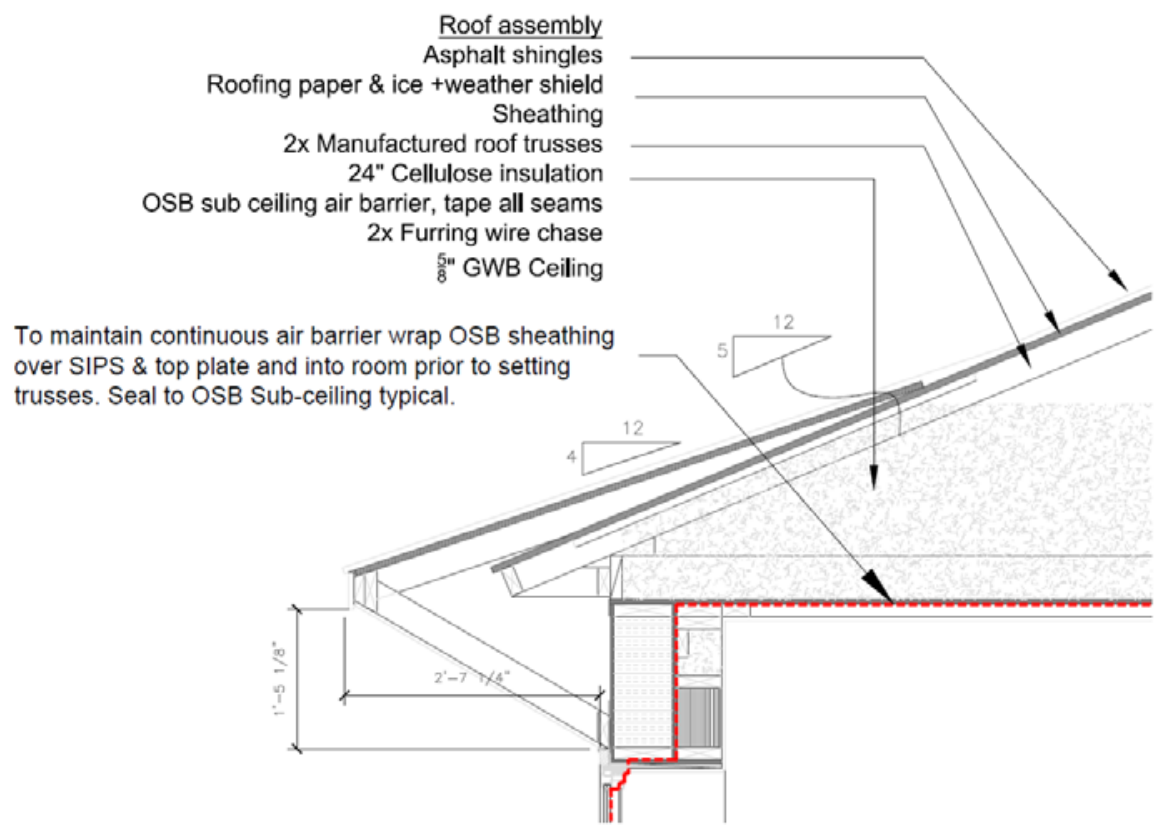

Figure 12. Roof detail

Source: BarlisWedlick Architects

\subsection{Space Conditioning}

A single ductless wall-mounted mini-split heat pump (Mitsubishi MSZ-FH12NA) was used for all space heating and cooling. Mini-split heat pumps are ideal for minimizing energy use in smaller homes and have variable capacities that achieve a good match with buildings that have low space-conditioning loads. Because of the relevance to the $\mathrm{CCHH}$ townhome design, literature on the use of point-source space conditioning systems in high-performance homes was reviewed. Ueno and Loomis (2015) provide a comprehensive literature summary. Some of their major conclusions are:

- One- and two-point space-conditioning systems can cost significantly less than traditional systems and have been demonstrated to work well in highly insulated, airtight, and compact houses.

- Space temperature variation across the house is typically a function of house operation.

- Eliminating ductwork via point-source space-conditioning units is beneficial and can be easier than relocating ductwork into the conditioned space.

- Opening and closing doors often impacts interior temperatures significantly. Temperatures drift apart when bedroom doors are closed.

- Thermostat setbacks result in larger temperature variations, long recovery times, and often increased energy consumption (in the case of mini-splits because they are less efficient at high loads) and are strongly discouraged.

- Transfer fans help even out temperatures across a home but only to a limited point. 
- Locating a single heat source on the first floor can work well in a well-insulated, airtight, and compact two-story house. Locating the only cooling source on the first floor can result in overheated second floor due to thermal buoyancy.

Additionally, monitoring by The Levy Partnership of the two 2013 CCHH near-Passive Houses (The Levy Partnership, Inc. and CDH Energy Corp. 2014), which also have point-source space conditioning using mini-split heat pumps, informed the design of the 2014 townhomes. Results from these homes were consistent with Ueno and Loomis' conclusions:

- Comfort: The heat pump on the first floor at the bottom of the stairs did not effectively cool the upstairs bedrooms. Through-floor transfer fans were added to the bedrooms, but residents reported they had little effect. Several were obstructed by furnishings. Upright fans were used in summer, but the bedrooms were sometimes uncomfortably hot. The data did show summer periods with outdoor temperatures cooler than second-floor temperature, which indicates that opening windows could have alleviated overheating. Neither floor had direct cross ventilation. On the first floor, cross ventilation could be achieved by opening the rear door, but lack of a screen and security concerns inhibited that approach. Cooling problems may also have been exacerbated by the open stair to the basement, which may have served as a repository for cool air from the first floor. Sealing off that opening may prevent a significant amount of cooled air from flowing down to the basement.

- Operation: Unanticipated homeowner behavior may have aggravated comfort problems. In particular, occupants neglected to use windows for natural cooling, and they tended to switch the heat pump on and off manually rather than allowing the house to achieve more even temperatures over time. Under these circumstances a single point-source for heating and cooling on the first floor was unable to achieve consistent comfort temperatures throughout the year.

In light of the literature review and past experiences with the 2013 near-Passive Houses, several features were incorporated into the new designs. A single unit rather than two (one on each floor) was chosen to minimize costs. The following approach was taken to mitigate comfort problems caused by stratification of conditioned air:

- The indoor unit was located on the second floor where it could more effectively cool bedrooms (a high mini-split location has been used successfully for heating and cooling in other Passive House projects (The Levy Partnership, Inc. and CDH Energy Corp. 2014).

- The first floor is not connected to a basement, so cooled air will not flow down below the first floor level.

- Ceiling fans were used rather than through-wall transfer fans, as attempted in the earlier $\mathrm{CCHH}$ townhome project, in an effort to circulate larger volumes of air between floors.

- In addition to the open stair, another floor opening was designed into the house (Figure 14) to provide a second pathway for air to circulate between floors, pushed by the action of a ceiling fan in the second-floor landing. 
- The residents would be trained to operate the heat pumps by leaving them on at a constant set point rather than turning them on and off frequently. This was to avoid high short-term heating and cooling loads and easily meet the set point to provide comfort.

Space-conditioning-related comfort and energy demand were further addressed by the following:

- Window location was altered on the second floor to promote better cross-ventilation, and windows were specified as casement rather than tilt-turn to promote easy opening even with furniture nearby.

- Overhangs were added to prevent the overheating that presented issues in the 2013 nearPassive Houses (The Levy Partnership, Inc. and CDH Energy Corp. 2014).

\subsection{Ventilation}

Efficient heat or energy recovery ventilation is essential to the healthy operation of a Passive House. Two balanced ventilation strategies were considered for this Passive House project: a traditional central ducted system and a point-source solution.

A common ventilation strategy for ENERGY STAR homes is a continuously running bathroom exhaust fan for fresh-air ventilation and kitchen and bathroom switch-operated exhaust fans for local ventilation. Typically, Passive Houses have a ducted ventilation system including a HRV. A point-source alternative was considered because it would eliminate the need for ventilation ductwork and more reliably deliver the specified amounts of fresh air to individual rooms. In the first set of townhomes built by CCHH in 2013, the site-installed distribution system did not deliver the specified airflow, particularly to the second-floor bedrooms. A point-source system would eliminate that potential problem and be simpler for nonspecialists to install.

The point-source ventilation equipment considered was the Lunos e2. These small, through-wall units operate in pairs; one provides supply and the other provides exhaust at identical rates. As air moves through the units, the heat from exhausting air (or incoming air in summer) warms the ceramic heat exchanger core in the exhausting unit (or supplying unit in summer). After 90 seconds both units reverse flow directions and the heat that was stored in the core is released into the room (or to the outside in summer). The second unit in the pair operates identically, but always in the opposite direction of the first to maintain balanced ventilation. Units are typically distributed around the house in rooms that require ventilation. One or more pairs may be used depending on the total ventilation needs of the building.

The design airflow rate (maximum required) for each home using Passive House criteria is 77 CFM and the average flow required is $50 \mathrm{CFM}(0.30 \mathrm{ACH})$. The ASHRAE 62.2 requirement to fulfill ENERGY STAR is 48 CFM. The E2 units deliver (and exhaust) 17 CFM at medium setting and $22 \mathrm{CFM}$ at high setting. Therefore, four pairs would achieve the balanced design ventilation flow rate. A layout of the point-source ventilation system for the Habitat Townhomes is provided in Figure 13: one unit would be located in each bedroom and five would be located on the first floor for a total of eight units (four pairs). In addition to the e 2 units, separate kitchen and bathroom local exhaust ventilation would be provided by traditional switch-operated fans (required for ENERGY STAR). 


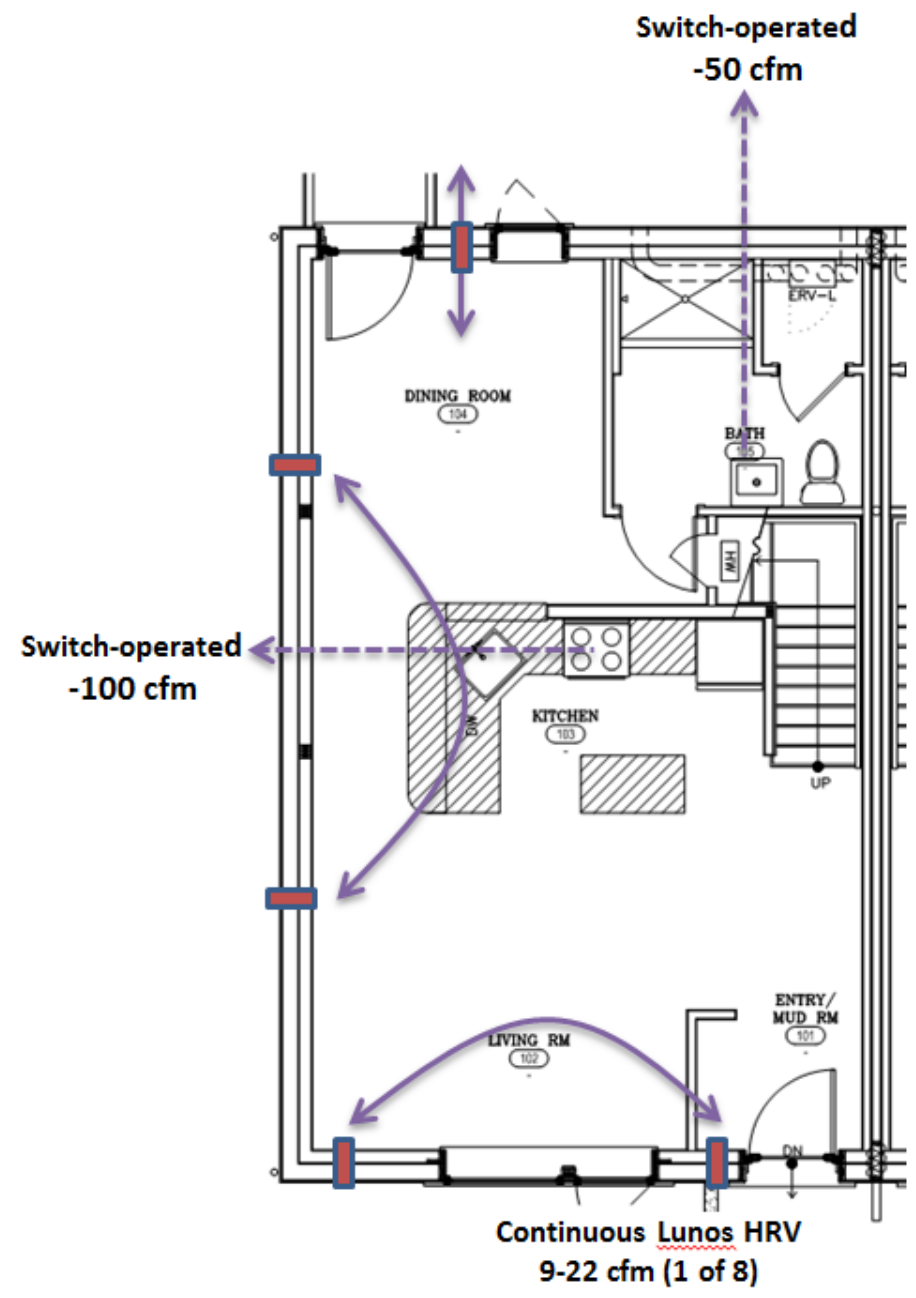

Typical unit: First floor

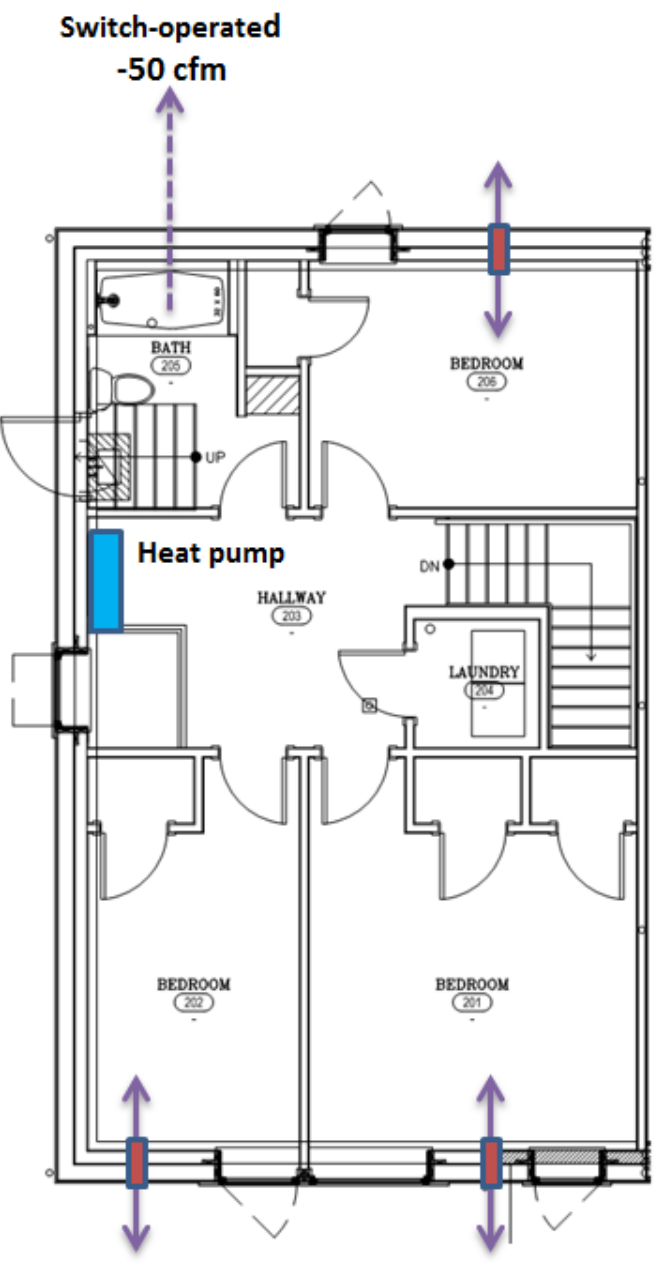

Typical unit: Second floor

Figure 13. Point-source ventilation schematic

Source for base drawing: BarlisWedlick Architects

The ducted central system option is shown in Figure 14. Estimates of the costs associated with each solution, inclusive of discounts offered to Habitat for Humanity, are provided in Table 5 and Table 6. 


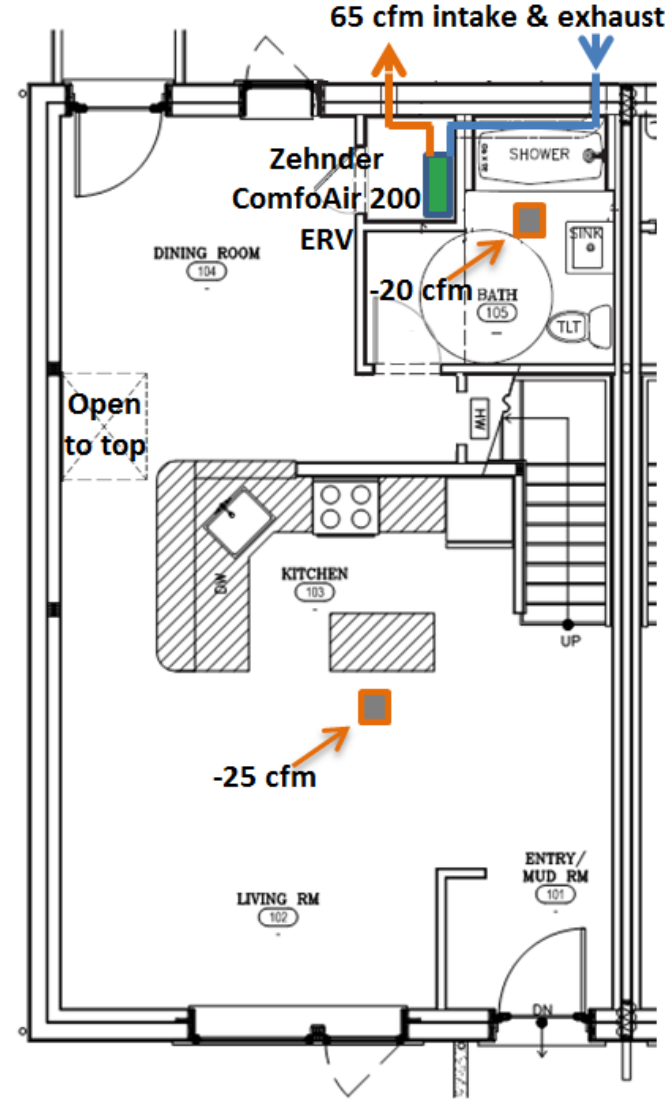

Typical unit: First floor

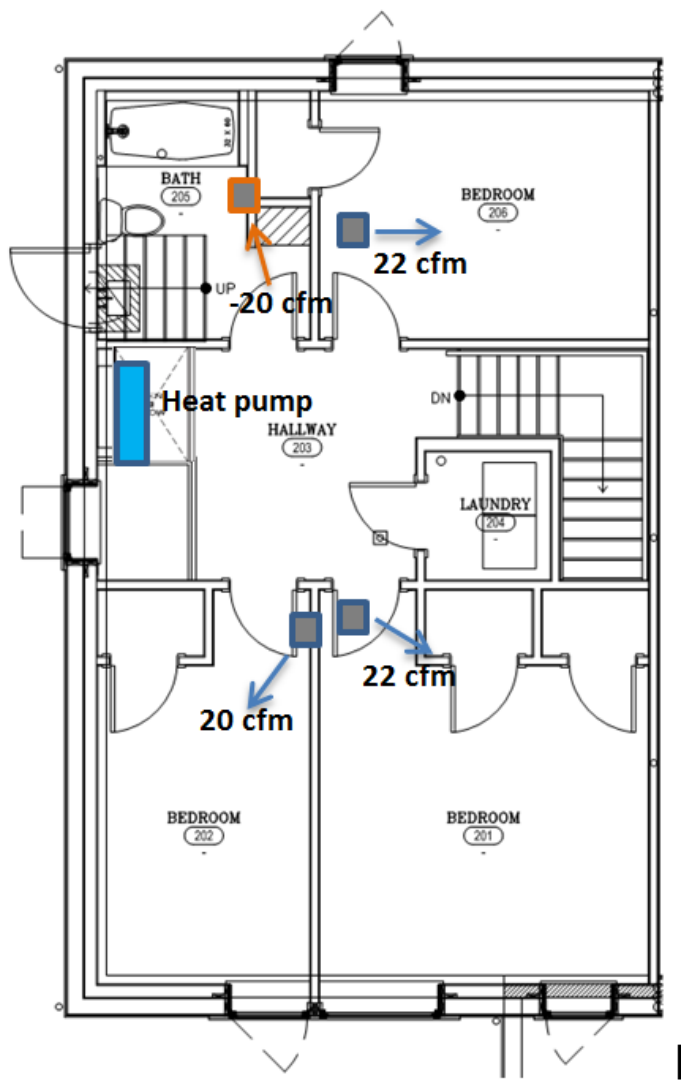

Typical unit: Second floor

Figure 14. Central ventilation schematic

Source for base drawing: BarlisWedlick Architects

Table 5. Distributed Point-Source Ventilation System Major Components and Costs

\begin{tabular}{|c|c|c|c}
\hline Item & Quantity & $\begin{array}{c}\text { Approximate } \\
\text { Price }\end{array}$ & Total Cost \\
\hline Lunos E2 & 4 pair & $\$ 1,097.50 /$ pair & $\$ 4,390$ \\
\hline Banos E2 Installation Fans & 8 & $\$ 125$ each & $\$ 1,000$ \\
\hline Range Hood & 2 & $\$ 150$ each & $\$ 300$ \\
\hline $\begin{array}{c}\text { Bath Fan Installation and Miscellaneous } \\
\text { Materials (Ducts, Dampers) }\end{array}$ & 1 & $\$ 250$ each & $\$ 250$ \\
\hline $\begin{array}{c}\text { Range Hood Installation and Miscellaneous } \\
\text { Materials (Ducts, Dampers) }\end{array}$ & 1 & $\$ 125$ each & $\$ 250$ \\
\hline Total & & & $\$ 235$ each \\
\hline
\end{tabular}


Table 6. Central Ventilation System Major Components and Costs

\begin{tabular}{c|c}
\hline Item & Approximate Price Each \\
\hline Zehnder ComfoAir 200 & $\$ 3,197$ \\
\hline $\begin{array}{c}\text { Zehnder Distribution System with 3 Supplies and } \\
\text { Exhausts; 6-in. Comfopipe Ductwork at Intake and } \\
\text { Exhaust, 3-in. Comfotube Ductwork at Diffusers }\end{array}$ & $\$ 1,397$ \\
HRV Installation & $\$ 1,988$ \\
\hline Recirculating Range Hood and Installation & $\$ 300$ \\
Total & $\$ 6,882$ \\
\hline
\end{tabular}

Two factors drove the decision to use a central ventilation system:

1. The large number of distributed units required nearly eliminated the cost advantage of the distributed system. The total cost of the distributed system, including bath and kitchen ventilation and installation, was estimated at $\$ 6,425$, compared to the central system cost of $\$ 6,882$.

2. Despite the manufacturer-reported efficiency of $90.6 \%$ ( 475 High Performance Building Supply), the point source units were not certified by the Passive House Institute, which requires a low $(75 \%)$ heat recovery efficiency to be used in the certification calculations as opposed to $92 \%$ for the central system.

A summary of the advantages and disadvantages of each system type is provided in Table 7.

Table 7. Comparison of Point-Source versus Central Ducted Ventilation System

\begin{tabular}{|c|c|c|}
\hline Consideration & Point Source & Central Ducted \\
\hline Cost & $\begin{array}{l}\text { Potentially lower for smaller homes } \\
\left.\text { or apartments (less than } 1,000 \mathrm{ft}^{2}\right) \\
\text { where only two pairs are required }\end{array}$ & $\begin{array}{l}\text { Probably lower for homes larger than } \\
\qquad 1,000 \mathrm{ft}^{2}\end{array}$ \\
\hline $\begin{array}{l}\text { Kitchen and Bath } \\
\text { Exhaust }\end{array}$ & $\begin{array}{l}\text { Requires separate system, which } \\
\text { adds cost }\end{array}$ & $\begin{array}{l}\text { Typically included in the central } \\
\text { system }\end{array}$ \\
\hline Distribution & $\begin{array}{l}\text { More reliable as no ducts are } \\
\text { involved }\end{array}$ & $\begin{array}{l}\text { Must be carefully designed, } \\
\text { constructed, and tested to ensure } \\
\text { adequate flow }\end{array}$ \\
\hline Installation & Mainly simple electrical connections & $\begin{array}{l}\text { Requires knowledgeable heating, } \\
\text { ventilating, and air-conditioning } \\
\text { contractor }\end{array}$ \\
\hline $\begin{array}{l}\text { Passive House } \\
\text { Certification }\end{array}$ & $\begin{array}{l}\text { Not yet Passive House certified, so } \\
\text { efficiency rating used for } \\
\text { certification is low }\end{array}$ & $\begin{array}{c}\text { Units available from a few } \\
\text { manufacturers that have Passive } \\
\text { House certification }\end{array}$ \\
\hline Controls/Features & $\begin{array}{l}\text { Simple off-low-high controls for } \\
\text { each pair of units }\end{array}$ & $\begin{array}{l}\text { Central controls typical with many } \\
\text { features such as programming, } \\
\text { bypass (for natural summer cooling) } \\
\text { boost modes }\end{array}$ \\
\hline
\end{tabular}




\section{Modeling}

The homes were modeled using three energy modeling software packages: Passive House Planning Package U.S. version 12-10-09, REM/Rate version 14.6.1 and Building Energy Optimization (BEopt) version 2.3.0.2. Table 8 shows the energy projections for each model. Total annual site energy consumption is very similar between all software packages. REM/Rate shows higher end-use estimates in general, except for in "Other." The PHIUS limits required for certification are shown in the column at right.

Table 8. Comparison of Energy Models per Housing Unit

\begin{tabular}{|c|c|c|c|c|}
\hline & \multicolumn{3}{|c|}{ Modeling Results } & \multirow[b]{2}{*}{$\begin{array}{c}\text { PHIUS+ } 2015 \\
\text { Regional } \\
\text { Annual } \\
\text { Limits* } \\
(\mathrm{kWh} / \mathrm{yr})\end{array}$} \\
\hline & $\begin{array}{c}\text { PHIUS+ } 2015 \\
\text { Passive House } \\
\text { Planning Package } \\
\text { US V12-09.09 } \\
(\mathbf{k W h} / \mathbf{y r})\end{array}$ & $\begin{array}{c}\text { REM/Rate } \\
\text { V 14.6.1 } \\
\text { (kWh/yr) }\end{array}$ & $\begin{array}{c}\text { BEopt V } \\
2.3 .0 .2 \\
(\mathrm{kWh} / \mathrm{yr})\end{array}$ & \\
\hline Total Energy & 6,414 & 6,922 & 6,452 & 7,845 \\
\hline $\begin{array}{l}\text { Total Space } \\
\text { Conditioning }\end{array}$ & 589 & 1,320 & 320 & 1,019 \\
\hline Heating & 432 & 792 & 82 & 721 \\
\hline Cooling & 157 & 528 & 238 & 298 \\
\hline Domestic Hot Water & 2,565 & 3,314 & 2,933 & - \\
\hline $\begin{array}{c}\text { Other (plug loads, } \\
\text { appliances, etc.) }\end{array}$ & 3,260 & 2,288 & 3,203 & - \\
\hline
\end{tabular}

* Based on PHIUS+ 2015 requirements for $1,340-\mathrm{ft}^{2}$ conditioned floor area per unit

\subsection{Optimizing Building Energy Optimization Software}

BEopt was used to assess the annualized energy-related costs of the upgrades used to achieve Passive House efficiency levels compared to baseline code and ENERGY STAR Version 3. Modeling assumptions are included in Appendix B. Incremental costs for the Passive House upgrades above the ENERGY STAR minimum requirements costs are shown in Table 9. The costs for the measures making up the theoretical ENERGY STAR house were taken from the BEopt database. Passive House costs were obtained from project invoices. Because the team felt strongly about eliminating combustion appliances in a tightly built Passive House, all Passive House specifications are electric; the ENERGY STAR base of comparison is not. Some of the costs incorporate a discount that Habitat receives as a nonprofit; this is indicated in the detailed cost list in Appendix A. Costs do not include soft costs for energy engineering, inspections, and testing. 
Table 9. Upgrade Costs: ENERGY STAR Version 3 versus Passive House Specifications

\begin{tabular}{|c|c|c|c|c|}
\hline Component & ENERGY STAR Specification & Passive House Specification $^{a}$ & Incremental Cost $^{\mathrm{b}}$ & $\begin{array}{c}\text { Total } \\
\text { Incremental } \\
\text { Cost per Unit }\end{array}$ \\
\hline $\begin{array}{l}\text { Exterior Above- } \\
\text { Grade Walls }\end{array}$ & R-19 $2 \times 6$ with fiberglass batts & $\begin{array}{l}2 \times 6 \text { with dense pack } \\
\text { cellulose }(\mathrm{R}-19)\end{array}$ & $\$ 0.25 / \mathrm{ft}^{2}$ wall area & $\$ 377$ \\
\hline Sheathing & OSB & $\begin{array}{l}\text { DOW building wrap plus R-33.3 7.8- } \\
\text { in.-thick Neopor SIPs }\end{array}$ & $\$ 8.49 / \mathrm{ft}^{2}$ wall area & $\$ 12,995$ \\
\hline Ceiling Insulation & $\mathrm{R}-38$ fiberglass batt & R-91 cellulose & $\$ 3.48 / \mathrm{ft}^{2}$ ceiling area & $\$ 2,822$ \\
\hline $\begin{array}{l}\text { Framed Floor } \\
\text { Insulation }\end{array}$ & $\mathrm{R}-30$ fiberglass batt & $\begin{array}{c}\text { R-69 dense-pack cellulose and Neopor } \\
\text { basement ceiling }\end{array}$ & $\begin{array}{l}\$ 4.64 / \mathrm{ft}^{2} \text { first-floor } \\
\text { area }\end{array}$ & $\$ 3,764$ \\
\hline Air Leakage & $4 \mathrm{ACH} 50$ & $0.8 \mathrm{ACH} 50$ & $\$ 0$ & $\$ 0$ \\
\hline $\begin{array}{l}\text { Mechanical } \\
\text { Ventilation }\end{array}$ & $\begin{array}{l}\text { Bathroom exhaust fan running } \\
\text { continuously with adjustable } \\
\text { local exhaust plus kitchen range } \\
\text { hood exhausted to the outside }\end{array}$ & $\begin{array}{l}\text { Zehnder ComfoAir } 200 \mathrm{HRV} \text { with } \\
\text { ComfoTube distribution system }\end{array}$ & $\$ 5,826$ each & $\$ 5,826$ \\
\hline Space Conditioning & $\begin{array}{l}\text { Gas-fired warm air furnace }(90 \% \\
\text { AFUE) and split system AC } \\
\text { (SEER 13) fully ducted (4 } \\
\left.\text { CFM25/100 } \mathrm{ft}^{2}, \mathrm{R}-6\right)\end{array}$ & $\begin{array}{l}\text { Wall-mounted Mitsubishi ductless } \\
\text { mini-split heat pump (MSZ-FH12NA } \\
\text { and MUZ-FH12NA) (SEER 26, HSPF } \\
\text { 12.5, 1-ton capacity) }\end{array}$ & $-\$ 2,757$ each & $-\$ 2,757$ \\
\hline Water Heating & $\begin{array}{l}\text { Gas-fired storage tank ( } 40 \mathrm{gal} \text {, } \\
0.67 \text { energy factor) }\end{array}$ & $\begin{array}{l}\text { Electric water heater with storage tank } \\
\text { (40 gal, } 0.95 \text { energy factor) }\end{array}$ & $-\$ 333$ each & $-\$ 333$ \\
\hline Lighting & $80 \%$ compact fluorescent lamps & $100 \%$ compact fluorescent lamps & $\begin{array}{l}\$ 0.01 / \mathrm{ft}^{2} \text { conditioned } \\
\text { area }\end{array}$ & $\$ 7$ \\
\hline Windows & $\begin{array}{l}\text { Double pane, medium gain, low- } \\
\text { e, insulated frame, air fill (U } 0.3 \text {. } \\
\text { SHGC } 0.46,12 \% \text { of wall area) }\end{array}$ & $\begin{array}{l}\text { Alpen windows with triple glazed } \\
\text { fiberglass frame: U-value: } 0.18 \text { (south } \\
\text { façade), SHGC: } 0.56 \text { (south façade), } \\
15 \% \text { of wall area) }\end{array}$ & $\begin{array}{c}\$ 0.48 / \mathrm{ft}^{2} \text { window } \\
\text { area }\end{array}$ & $\$ 1,117$ \\
\hline Doors & $\begin{array}{l}\text { Swinging entry, }<1 / 2 \text {-Lite } \\
\text { glazing, steel frame, U } 0.66\end{array}$ & $\begin{array}{l}\text { Klearwall triple-glazed fiberglass } \\
\text { frame full lite (U 0.16, SHGC } 0.49 \text { ) }\end{array}$ & $\$ 62.85 / \mathrm{ft}^{2}$ door area & $\$ 2,640$ \\
\hline $\begin{array}{l}\text { Total Incremental } \\
\text { Costs }\end{array}$ & & & & $\$ 26,457$ \\
\hline
\end{tabular}

R-values refer to the assembly R-value

${ }^{\mathrm{b}}$ Cost of upgrade to achieve Passive House standards compared to meeting ENERGY STAR Version 3 minimum requirements 
Figure 15 shows the annualized energy-related costs plotted against source energy savings for four specification options: baseline code (IECC 2009) (contains gas water heater), ENERGY STAR Version 3 (gas water heater), and two Passive House versions (electric water heater as built and hypothetical gas water heater).

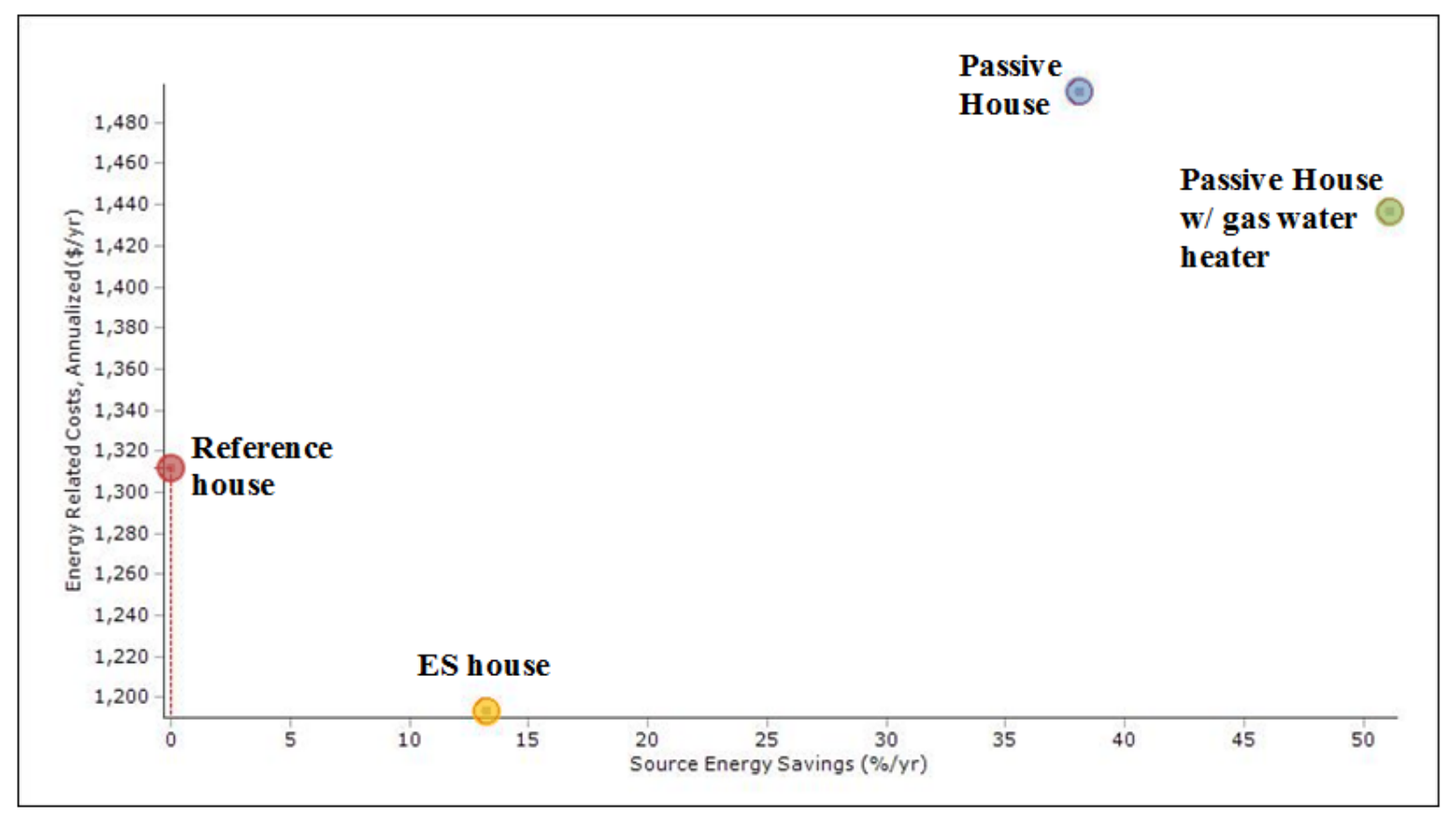

Figure 15. BEopt annualized energy-related costs

The Passive House is an all-electric house; the IECC 2009 house and the ENERGY STAR house use gas for space and water heating. As a result, the Passive House has the highest annualized energy-related costs ${ }^{2}$ owing to the higher construction costs and a higher price of electricity compared to gas. The electric water heater in the Passive House was replaced with a gas water heater that was used in the ENERGY STAR house for comparison through modeling (Figure 16). Along with reducing the annualized energy-related costs by $\$ 243$, the Passive House with gas water heater shows a source energy savings of nearly $35 \%$ from the ENERGY STAR home and 50\% from the Baseline IECC 2009 house. BEopt financial modeling assumptions used for all three models are provided in Appendix B.

\footnotetext{
${ }^{2}$ BEopt calculates the annualized energy-related costs by annualizing the energy-related cash flows over the analysis period. Cash flows consist of mortgage/loan payments, replacement costs, utility bill payments, mortgage tax deductions (for new construction), and residual values. Costs, excluding mortgage/loan payments, are inflated based on the time they occur in the analysis period. The cash flows are annualized by determining the present worth of the cash flow by converting the total cost for each year to the value at the beginning of the analysis period (NREL 2012).
} 


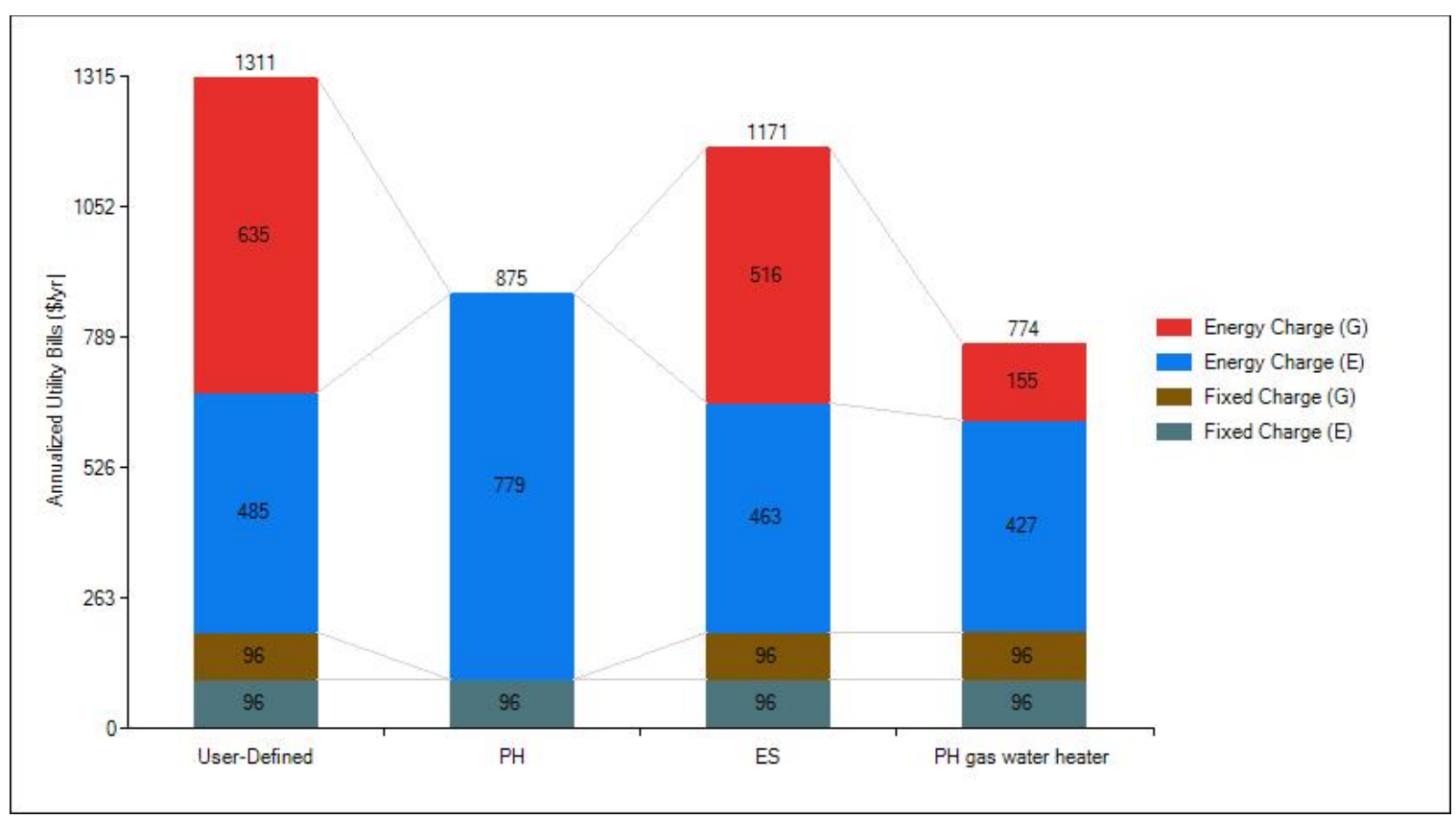

Figure 16. BEopt annual utility costs

Although the as-built Passive House has higher incremental costs, it does have lower monthly utility bills (Figure 16). This was a major factor for $\mathrm{CCHH}$ to continue its pursuit of effective Passive House design. The Passive House bills are projected to be \$296/year lower than those of the ENERGY STAR version. When the electric water heater is replaced with a gas water heater, the utility bills are \$396 lower. However, considering all energy-related cash flows over time, the as-built Passive House's annualized energy-related costs are $\$ 301$ higher than those of the ENERGY STAR home. Incremental construction costs to realize the builder's vision of a Passive House versus a hypothetical one built to ENERGY STAR Version 3 standards was \$26,457, as seen in Table 9. 


\section{Discussion}

$\mathrm{CCHH}$ is a cost-conscious builder-all its clients are low-income households. However, because Habitat chapters are mission-driven to provide affordable housing, and because they enter into long-term relationships with their clients by holding the mortgage, they are also motivated to provide housing with low operating costs. Therefore, energy efficiency, a healthful indoor environment, and durability are important factors. ENERGY STAR, ZERH, and Passive House are pathways to achieving these goals that provide independent verification and recognition.

Although not yet cost-optimized, the Passive House pathway does help CCHH meet its goal of offering housing with low annual energy costs (\$296 lower than ENERGY STAR). For this project, $\mathrm{CCHH}$ chose to pursue this mission by building to Passive House standards in a continuing exploration of costs and technologies. Its long-term goal is to develop a system that allows CCHH to cost-effectively meet Passive House standards. The team built on the experience of the previous $\mathrm{CCHH}$ townhome project by identifying opportunities to improve cost-effectiveness for the organization and its clients and significantly improve energy performance. Because $\mathrm{CCHH}$ uses a volunteer workforce for many tasks, its cost framework differs from that of for-profit builders. Unskilled and semiskilled labor costs are very low. However, trades such as electrical, plumbing, and heating, ventilating, and air conditioning are typically contracted. Similarly, some materials and products are procured at steep discounts or donated and alter the cost-benefit relationships. The Passive Houses were built with electric water heaters, but given the modeling results, this choice in water-heating method may be worth revisiting in future projects to save money and source energy.

\subsection{Challenges of High-Performance Certification with a Habitat Home}

Risks associated with achieving exemplary energy performance with a Habitat for Humanity home include, but are not limited to, the following:

- The volunteer labor force may be neither adequately trained nor capable of installing building components to the professional quality needed to achieve high Passive House and ZERH standards. To overcome this, an experienced professional must oversee and provide training for the installation of certain building components. Periodic performance testing must be performed at critical steps.

- The costs to meet Passive House and/or ZERH standards may exceed Habitat for Humanity's definition of cost-effectiveness.

- Habitat projects do not always have full-time professional construction managers or supervisors. This can lead to negative outcomes, especially with respect to the air-sealing requirements of a Passive House. Air sealing must be a high priority at nearly all stages of construction. A designated person should be at the site regularly who:

$\circ$ Understands the air-sealing strategy

- Has access to the necessary air-sealing products and materials

- Coaches and trains volunteers to implement the air-sealing strategy

$\circ$ Ensures that contractors and other workers do not compromise the air barrier. 
- A significant risk of pursuing ENERGY STAR (and associated incentives, where available) in combination with Passive House certification is a conflict between the common kitchen ventilation strategy for Passive House (continuous 24 to 36 CFM exhaust in the kitchen via an HRV or energy recovery ventilator in combination with a recirculating range hood) and the ENERGY STAR requirement of 100 CFM range hood exhausted directly to the outside (or, alternatively an exhaust fan in the kitchen capable of 5 air changes per hour based on kitchen volume) (EPA 2015). ENERGY STAR resolves this conflict by providing an exemption that permits the Passive House approach (at continuous 25 CFM minimum) if the project is Passive House certified. However, if the project does not achieve certification because, for example, it misses the blower door test limit, it would lose this exemption altogether and be required to install the ENERGY STAR kitchen exhaust to achieve ENERGY STAR certification, at a significant cost and energy penalty. Recent studies have shown highly variable performance in range-hood ventilation - both in capture efficiency and in pollutant removal-suggesting that ventilation through range hoods as opposed to ceiling exhausts does not always improve indoor air quality (Delp and Singer 2012; Singer, William, and Price 2012). 


\section{Conclusions}

\subsection{Research Questions}

This research addresses the following questions:

1. What low-cost, high-R-value, and airtight envelope system is suitable for new attached homes in IECC Climate Zone 5 that can be successfully implemented by a largely volunteer labor force? What are the costs and resulting performance characteristics?

This Habitat builder elected to use a $2 \times 6$ frame wall with a SIP curtain wall system and a ventilated attic over an air-sealed oriented strand board ceiling. The frame wall provided work for volunteer labor; the SIP wall provided a thermal-bridge-free and airtight layer that brought the wall up to R-52.5. The SIP curtain wall added $\$ 13,000$ to the wall system cost, but it did achieve the desired performance result of low measured air leakage despite the lack of construction crew expertise. It is likely that a doubleframed wall would have been cheaper, but achieving the necessary airtightness may have been more difficult because of using volunteer labor.

2. How can point-source space-conditioning systems, and possibly ventilation systems, be successfully implemented into moderately sized, low-load, affordable townhomes in IECC Climate Zone 5? What are the costs and performance characteristics?

Because of low space-conditioning loads, the Passive House units are able to use small mechanical systems to meet thermal demands, reducing both ductwork and total costs. With thoughtful placement of the mini-split heat pump and a compatible floor plan, comfort can be achieved with a point-source system. As discussed in Section 2.4, lessons from previous work informed space-conditioning design decisions for the new homes that aimed to improve upon CCHH's model of the Passive House. So far (in the cooling season), these components seem to be successful in terms of projected energy use and preliminary reported occupant comfort.

A point-source ventilation system was not used in this project because costs were on par with the central system (which was provided to Habitat at a 30\% discount) and because the point-source units did not have Passive House-certified heat-recovery values. A pointsource system would be cost-effective for smaller homes (up to about 1,000 $\mathrm{ft}^{2}$ ) and/or for homes that are not seeking Passive House certification.

3. What are the costs and systems integration issues associated with a super-insulated, highperformance, affordable townhome project in Climate Zone 5? How can these issues be successfully resolved?

Costs to achieve Passive House certification were about \$26,000 higher per unit than those for construction to meet minimum ENERGY STAR certification. This represents about 18\% of total Passive House construction costs. The largest cost component by far was the SIPs, which represented about half of this extra cost. Lower-cost wall methods such as double-wall framing (such as in the first set of Passive Townhomes [The Levy Partnership, Inc. and CDH Energy Corp. 2014] or exterior I-joists may be attempted in the future. Other significant upgrade costs were for the ventilation system, which is a common cost component in certified Passive Houses, floor insulation (specifically the 
Neopor), ceiling insulation, and doors. Windows were very low cost, partly because the manufacturer provides Habitat with a discount. The smaller mechanical system saved about $\$ 2,700$ per unit. No major systems integration issues were encountered.

To date the homes have been occupied during spring and summer months, and residents have reported excellent comfort with only a single mini-split heat pump. The residents have been following the recommendation to keep the unit on at a constant set point. They have verbally reported to $\mathrm{CCHH}$ that they are thermally and generally comfortable. Heating-season comfort levels have not yet been assessed. 


\section{References}

BASF. n.d. "BASF NEOPOR.” Accessed September 25, 2015: www.neopor.basf.us/.

CCHH. 2013. Builders, Bankers, Family Advocates. Hudson, NY: Columbia County Habitat for Humanity.

Defendorf, R. 2010. Green Building News. Accessed May 8, 2015: www.greenbuildingadvisor.com/blogs/dept/green-building-news/habitat-vermontcontinues-its-passive-house-journey.

Delp, W.W., and B.C. Singer. 2012. "Performance Assessment of U.S. Residential Cooking Exhaust Hoods." Environmental Science and Technology, 6167-6173.

DOE. 2012. "DOE Challenge Home Label Methodology." Accessed January 24, 2014: www1.eere.energy.gov/buildings/residential/pdfs/ch label_methodology 1012.pdf.

DOE. 2013. HUB of Innovation for High Performance Homes.

DOE. 2015. "DOE Zero Energy Ready Home National Program Requirements (Rev. 05)." Accessed September 21, 2015: http://energy.gov/sites/prod/files/2015/05/f22/DOE\%20Zero\%20Energy\%20Ready\%20Ho me $\% 20$ National $\% 20$ Program $\% 20$ Requirements $\% 20$ Rev05\%20-\%20Final_0.pdf.

EPA. 2015. "Rater Field Checklist ENERGY STAR Certified Homes, Version 3/3.1 (Rev. 08)." Accessed July 22, 2015: www.energystar.gov/ia/partners/bldrs_lenders_raters/downloads/rev_8/Rater\%20Checklist s\%20v101\%202015-06-26 clean fillable 508.pdf?8255-eac0.

Feist, W., J. Schnieders, V. Dorer, and A. Haas. 2005. "Re-inventing Air Heating: Convenient and Comfortable within the Frame of the Passive House Concept." Energy and Buildings, 37(11): 1186-1203.

Foster, J. M. 2011. "Superefficient Home with Big Ambitions, Built by Students on a Hoboken Lot." The New York Times, September 17, p. A18.

Gibson, S. 2014. Green Building News. Accessed May 8, 2015: www.greenbuildingadvisor.com/blogs/dept/green-building-news/habitat-s-highperformance-experiment.

Gonzales, C. 2010. "Passive House - Affordable Eco-Habitats." Accessed May 8, 2015: http://habitatbozeman.org/other/passive-house-affordable-ecohabitats.

Habitat for Humanity in Whatcom County. (2012). Passive Building. Retrieved May 8, 2015, from Habitat for Humanity Whatcom County: http://www.hfhwhatcom.org/passive-building.

Habitat for Humanity. (2014). Habitat for Humanity International Annual, Report FY2014. Habitat for Humanity. 
Habitat for Humanity. (2015). U.S. sustainable construction standards. Retrieved September Monday, 2015, from

http://www.habitat.org: http://www.habitat.org/lc/env/pdf/US_Construction_Standards.pdf.

Holladay, M. 2015. "Redefining Passivhaus.” Accessed September 22, 2015: www.greenbuildingadvisor.com/blogs/dept/musings/redefining-passivhaus.

NREL. 2012. BEopt v1.2 Help Menu: Annualized Energy Related Costs. Golden, CO: National Renewable Energy Laboratory.

Passipedia. 2014. "General Quality Requirements for Passive Houses/EnerPHit-Buildings." Accessed May 8, 2015: www.passipedia.org/passipedia en/planning/other_attributs for passive houses? $\mathrm{s} \% 5 \mathrm{~b} \% 5$ $\mathrm{d}=$ soft\&s $\% 5 \mathrm{~b} \% 5 \mathrm{~d}=$ criteria.

Passive House Institute, US. 2011. "What Is a Passive House?” Accessed January 24, 2014: www.passivehouse.us/passiveHouse/PassiveHouseInfo.html.

Passive House Institute. 2015. "Passive House Requirements." Accessed May 8, 2015: www.passiv.de/en/02 informations/02 passive-house-requirements/02 passive-houserequirements.htm.

Singer, B.C., D.W. William, and P.N. Price. 2012. "Performance of Installed Cooking Exhaust Devices." Indoor Air: International Journal of Indoor Environment and Health, 22(3): 224-234.

Tacoma/Pierce County Habitat for Humanity. 2015. "Ainsworth Vista." Accessed September 27, 2015: www.tpc-habitat.org/where_we_build/recently_completed/ainsworth.html.

The Levy Partnership, Inc., and CDH Energy Corp. 2014. Measured Performance of Three Passive Houses in New York State. Albany: New York State Energy Research and Development Authority.

Ueno, K., and H. Loomis. 2015. Long-Term Monitoring of Mini-Split Ductless Heat Pumps in the Northeast (Subcontract Report, SR-5500-63079). Golden, CO: National Renewable Energy Laboratory, www.nrel.gov/docs/fy15osti/63079.pdf?gathStatIcon=true.

United States Environmental Protection Agency. (2013, November). Indoor Air Plus Construction Specifications. Retrieved May 2015, from http://www.epa.gov/indoorairplus/pdfs/construction specifications.pdf.

Warren, J. 2012. "New Habitat House in Berea Is a Model of Energy Efficiency." Lexington Herald-Leader, July 14.

Wright, G.S., and Klingenberg, K. (2015). Climate-Specific Passive Building Standards (Subcontract Report, SR-5500-64278). Golden, CO: National Renewable Energy Laboratory. 


\section{Appendix A: Labor Costs and Discounts}

Table 10. Habitat Material/Labor Costs and Discounts-Entire Project (Two Housing Units)

\begin{tabular}{|c|c|c|c|c|c|c|}
\hline Item & Cost & Notes & Unit & Quantity & \$/Unit & $\begin{array}{c}\text { \$/Unit with } \\
\text { Labor }\end{array}$ \\
\hline Doors & $\$ 6,205$ & & $\mathrm{Ea}$ & 4 & $\$ 1,614$ & \\
\hline Windows and Doors & $\$ 15,807$ & & $\mathrm{ft}^{2}$ & 440 & $\$ 35.93$ & \\
\hline Cellulose Insulation-Floor & $\$ 1,076$ & 9.25-in.-thick R-34 & $\mathrm{ft}^{2}$ & 1,623 & $\$ 0.66$ & $\$ 1.91$ \\
\hline Cellulose Insulation-Walls & $\$ 1,207$ & 5.5-in.-thick R-20 & $\mathrm{ft}^{2}$ & 3,063 & $\$ 0.39$ & $\$ 1.14$ \\
\hline Cellulose Insulation Labor-Walls & $\$ 2,272$ & & $\mathrm{ft}^{2}$ & 3,063 & $\$ 0.74$ & \\
\hline Cellulose Insulation Labor-Ceiling & $\$ 5,254$ & & $\mathrm{ft}^{2}$ & 1,623 & $\$ 3.24$ & \\
\hline SIPs Material and Labor & $\$ 28,719$ & Core thickness -7.25 in.; R-33 & $\mathrm{ft}^{2}$ & 3,063 & \multirow{2}{*}{$\$ 9.74$} & \multirow{3}{*}{$\$ 9.74$} \\
\hline Crane Services & $\$ 1,100$ & Discounted from $\$ 2,700$ & $\mathrm{ft}^{2}$ & 3,063 & & \\
\hline Neopor Floor Insulation & $\$ 5,297$ & 8-in. $\times 4$-ft $\times 24-\mathrm{ft}$ slabs; qty of 15 & $\mathrm{BF}$ & 11,520 & $\$ 0.46$ & \\
\hline HRV Phase 1 (Distribution System) & $\$ 2,794$ & $30 \%$ Habitat discount & $\mathrm{Ea}$ & 2 & $\$ 4,594$ & $\$ 6,581$ \\
\hline Heat Pump Indoor Units & $\$ 1,225$ & & $\mathrm{Ea}$ & 2 & $\$ 612$ & \multirow{2}{*}{$\$ 3,575$} \\
\hline $\begin{array}{c}\text { Heat Pump Outdoor Units 1, } 2 \text { and } \\
\text { Mounting Bracket }\end{array}$ & $\$ 2,286$ & & $\mathrm{Ea}$ & 2 & $\$ 1,143$ & \\
\hline
\end{tabular}




\section{Appendix B: Building Energy Optimization Modeling} Assumptions

Table 11. BEopt Modeling Assumptions

\begin{tabular}{|c|c|}
\hline Mortgage Assumptions & \\
\hline Down Payment & $0 \%$ \\
\hline Mortgage Interest Rate & $4 \%$ \\
Mortgage Period & 30 years \\
\hline Marginal Income Tax Rate, Federal & $28 \%$ \\
\hline Marginal Income Tax Rate, State & $0 \%$ \\
\hline
\end{tabular}




\section{Appendix C: Photos of Columbia County Homes}
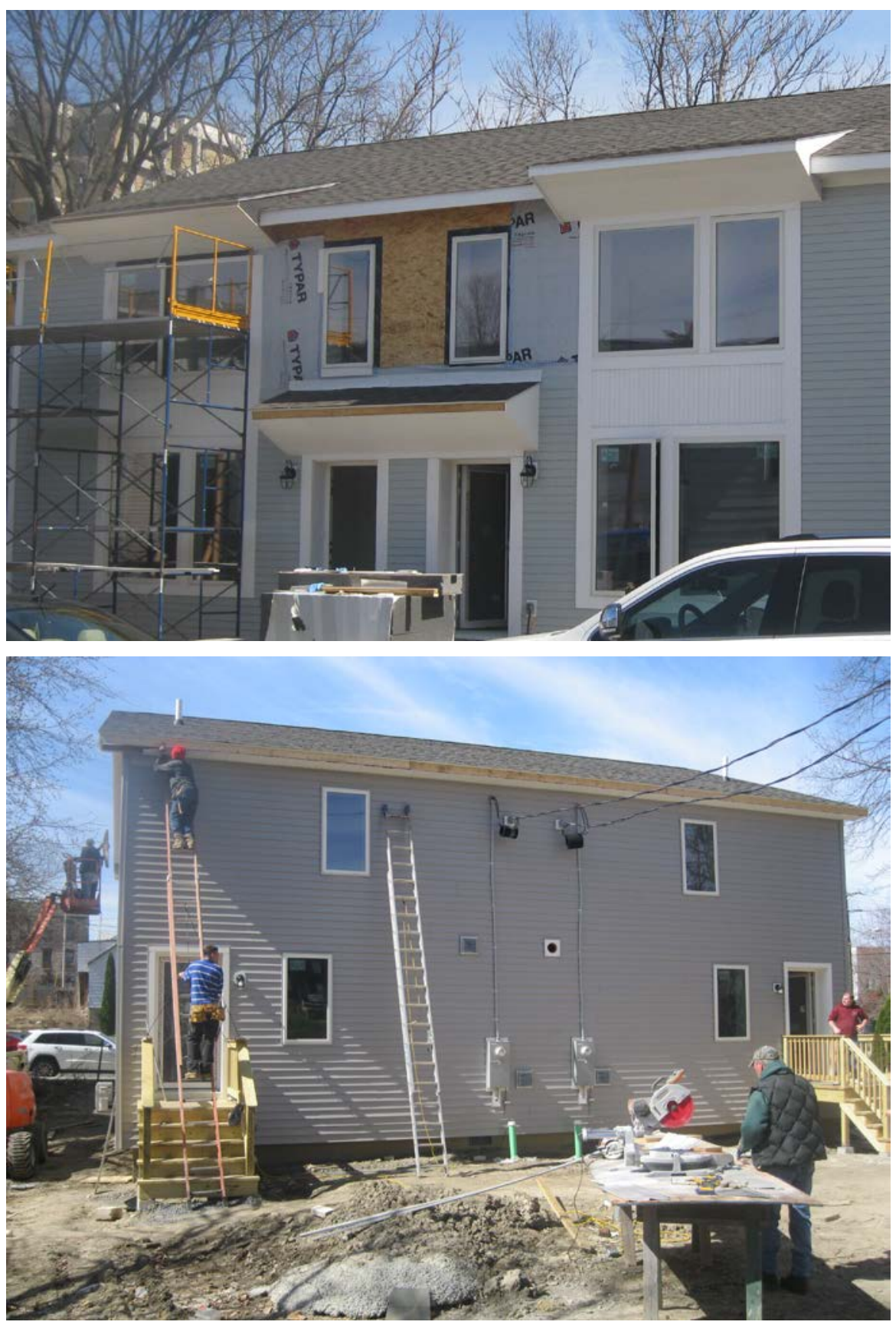


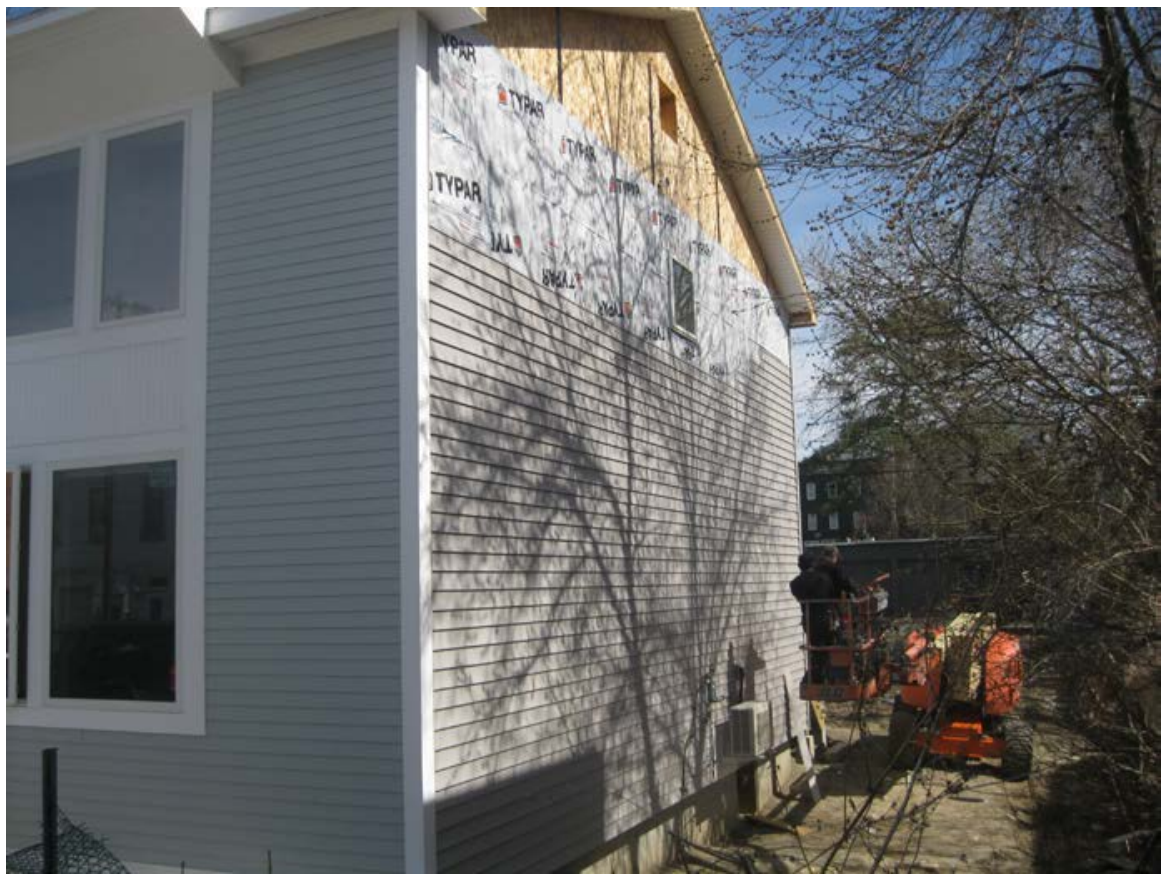


